Article

\title{
Cluster Analysis: A New Approach for Identification of Underlying Risk Factors and Demographic Features of First Trimester Pregnancy Women
}

\author{
Anna Karen Gárate-Escamilla ${ }^{1, *}$, Edelmiro Garza-Padilla ${ }^{2}$, Agustín Carvajal Rivera ${ }^{2}$, \\ Celina Salas-Castro ${ }^{2}$, Emmanuel Andrès ${ }^{3}$ (D) and Amir Hajjam El Hassani ${ }^{1}$ (D) \\ 1 NIT Lab, Univ. Bourgogne Franche-Comte, UTBM, F-90010 Belfort, France; amir.hajjam@utbm.fr \\ 2 Monterrey Institute of Technology and Higher Education, Monterrey 64700, Mexico; \\ edelmiro13@gmail.com (E.G.-P.); agustin.carvajal@itesm.mx (A.C.R.); dracelinasalas@gmail.com (C.S.-C.) \\ 3 Service de Médecine Interne, Diabète et Maladies Métaboliques de la Clinique Médicale B, \\ CHRU de Strasbourg, 67091 Strasbourg, France; emmanuel.andres@chru-strasbourg.fr \\ * Correspondence: anna.garate-escamilla@utbm.fr
}

Received: 12 June 2020; Accepted: 13 July 2020; Published: 15 July 2020

\begin{abstract}
Thyroid pathology is reported internationally in 5-10\% of all pregnancies. The overall aim of this research was to determine the prevalence of hypothyroidism and risk factors during the first trimester screening in a Mexican patients sample. We included the records of 306 patients who attended a prenatal control consultation between January 2016 and December 2017 at the Women's Institute in Monterrey, Mexico. The studied sample had homogeneous demographic characteristics in terms of age, weight, height, BMI (body mass index) and number of pregnancies. The presence of at least one of the risk factors for thyroid disease was observed in $39.2 \%$ of the sample. Two and three clusters were identified, in which patients varied considerably among risk factors, symptoms and pregnancy complications. Compared to Cluster 0 , one or more symptoms or signs of hypothyroidism occurred, while Cluster 1 was characterized by healthier patients. When three clusters were used, Cluster 2 had a higher TSH (thyroid stimulating hormone) value and pregnancy complications. There were no significant differences in perinatal variables. In addition, high TSH levels in first trimester pregnancy are characterized by pregnancy complications and decreased newborn weight. Our findings underline the high degree of disease heterogeneity with existing pregnant hypothyroid patients and the need to improve the phenotyping of the syndrome in the Mexican population.
\end{abstract}

Keywords: thyroid pathology; k-means; first trimester pregnancy; pregnancy complications; pregnancy risk factors

\section{Introduction}

Pregnancy has a profound impact on the thyroid gland and its function, making it the second most common endocrine disorder during pregnancy, after diabetes mellitus. Thyroid pathology has a variable incidence and depends on the series consulted; internationally, thyroid disorders are reported in between 5 and $10 \%$ of all pregnancies [1]. The prevalence of subclinical hypothyroidism during pregnancy is $3.0 \%$ to $5.0 \%$ [2]. The normal upper limit range of TSH during the first trimester is $2.5 \mathrm{mIU} / \mathrm{L}$ and $3.0 \mathrm{mIU} / \mathrm{L}$ for the second and third trimester [3]. Numerous risk factors for pregnancy have been reported to be associated with thyroid disease disorders, including overweigh [4], excessive salt intake [5-7] and high cholesterol levels [8]. The thyroid gland increases by $10 \%$ in size in countries without iodine deficiency such as Mexico. Thyroxine (T4) and triiodothyronine (T3) production increase by $50 \%$. These physiological changes can lead to hypothyroidism in the advanced stages of pregnancy in patients with iodine deficiency who were euthyroid in early pregnancy [9]. For 
women with undiagnosed thyroid disease, early screening may be the ideal opportunity to allow adequate treatment. The multitude of adverse effects associated with untreated thyroid disease leads to consideration of the potential benefits of screening during preconception and pregnancy $[9,10]$.

Hypothyroidism is an endocrinopathy characterized by an inappropriate action of thyroid hormones in the body, whose main cause is a lack of production by the thyroid gland. In countries without iodine deficiency, such as Mexico, the most common cause is autoimmune. However, we are still far from a global understanding of the problem, such as the relationship of maternal thyroid hormones with the fetus [11-13], the way the product develops its metabolic system from the iodine in the maternal diet $[7,14]$, the influence this has on neuronal development $[11,15]$ and, finally, the behavior of antithyroid antibodies during pregnancy [16], especially in the puerperium [17].

Subclinical hypothyroidism has not been clearly associated with adverse maternal-fetal outcomes such as overt hypothyroidism. The consequences of the former have been poorly defined, although most studies report an association between them and adverse pregnancy outcomes [3,9]. Abalovich and coworkers [18] reported that inadequate management with levothyroxine in women with manifest or subclinical hypothyroidism is associated with significant risks of miscarriage or preterm birth. However, studies have not been consistent in demonstrating these relationships. A retrospective study by Casey [19] showed that the risk of placental abruption and preterm delivery increased 2-3 times before 34 weeks of gestation in women without treatment for subclinical hypothyroidism, compared to euthyroid controls. Cleary-Goldman and coworkers [20] found no association between subclinical hypothyroidism and adverse perinatal outcomes in a cohort analysis of 10,990 women. Similarly, Männistö [21,22] also found no association in a large and retrospective cohort study.

Multiple prospective and retrospective studies have demonstrated an increased risk of complications during pregnancy $[18,23]$ associated with a slight increase in maternal TSH levels, especially in women with positive anti-TPO antibodies. Some risks are miscarriage, preeclampsia, hypertension, baby's brain development, hemorrhages, premature delivery, postpartum depression and low birth weight [24-31]. Only a limited number of studies have investigated the impact of levothyroxine treatment in patients with anti-TPO antibodies [3]. The randomized controlled study of Negro [23] showed a potential benefit of levothyroxine intervention at nine weeks gestation. Importantly, this study documented a reduction in adverse pregnancy outcomes only in patients with positive anti-TPO antibodies and mild hypothyroidism (defined as TSH $>2.5 \mathrm{mU} / \mathrm{L}$ ). This did not provide treatment to patients with negative antibodies. It was concluded that universal screening of high TSH concentrations does not improve the results compared to a strategy focused on high-risk patients. However, despite the limitations of the available studies on levothyroxine treatment in patients with subclinical hypothyroidism, the data appear to suggest a benefit in reducing the rate of miscarriages in patients with positive anti-TPO antibodies. It is reasonable to consider levothyroxine treatment for specific subgroups of patients with subclinical hypothyroidism.

Considering the research on pregnant women in the first trimester with thyroid diseases, studies in the literature are limited. $\mathrm{Li}$ [32] evaluated the relationship between miscarriage and first trimester thyroid function, finding that a TSH higher than $2.5 \mathrm{mIU} / \mathrm{L}$ increased the risk for miscarriage. Hernandez and coworkers [33] found an increased risk of perinatal loss, miscarriage and premature birth for patients between $2.5 \mathrm{mIU} / \mathrm{L}$ and $4.0 \mathrm{mIU} / \mathrm{L}$. In some countries, the authors concluded that $2.5 \mathrm{mIU} / \mathrm{L}$ is a low upper limit for first trimester pregnancy, with suggestions of an increase in the Indian population [34], the Chinese population [35], the Brazilian population (2.7 mIU/L) [36] and the Spanish population (4.72 $\mathrm{mIU} / \mathrm{L}$ ) [37]. Given the lack of information about the first trimester of pregnancy, this study addresses the creation of groups considering thyroid risk factors through clustering.

Cluster analysis is an unsupervised machine learning technique that aims to define subgroups of homogeneous individuals with attributes more similar to those of other groups or clusters [38,39]. Clustering is necessary to handle the interaction of multiple variables and has been used in the medical field for image processing, document classification and group creation [40]. Studies in other medical areas suggest that cluster analysis leads to a better understanding of the disease, as happens in 
the risk factors of coronary disease [41-43], chronic obstructive pulmonary disease (COPD) [44-47], asthma [48-51], tinnitus [52,53], insulin resistance in obese patients [54,55], diabetes [56-58], low back pain [59-63] and osteoarthritis [64-66].

Some groups found in the pregnancy-related literature are associated with hypertension $[67,68]$, preeclampsia [69,70], fetal growth restriction [71], miscarriage [72], incidence of pregnancy termination related to demographics [73], dietary patterns [74] and birth control related to maternal education, hygiene and nutrients [75]. There are some studies related to cluster analysis and thyroid disease, such as the prevalence of thyroid diseases in children and adolescents [76], spatial distribution and risk factors related to thyroid cancer [77-79], and finding the optimal number of thyroid disease clusters $[80,81]$.

However, there are few reports on clustering to better classify hypothyroidism during the first trimester of pregnancy, especially with risk factors and pregnancy complications. In this study, we applied cluster analysis to explore possible subgroups within a well-characterized population of first trimester pregnant women with hypothyroidism. This study would also help to identify potential risk factors for hypothyroidism in pregnant patients. The general objective of this research is to determine the clusters related to first trimester pregnant women with hypothyroidism in a sample of Mexican patients, with and without risk factors.

\section{Experimental Section}

\subsection{Dataset}

In this section, we describe the dataset used in the empirical testing of the first trimester pregnant women with thyroid disease (Table 1). This is a replicative, observational, cross-sectional, descriptive, retrospective study to determine the prevalence of hypothyroidism during screening of Mexican patients during the first trimester of pregnancy between January 2016 and December 2017, with and without risk factors, in a private Women's Institute in Monterrey, Mexico. This study was the first to be conducted on a Mexican population of northern Mexico that seeks to determine the prevalence of thyroid disease during the first trimester of pregnancy screening. The inclusion criteria were the records reporting TSH values during the first trimester of pregnancy. We excluded records of patients who initiated prenatal control in the second and third trimesters, incomplete records (not having all the variables to be analysed) and foreign patient, resulting in 306 patients with 55 features. A prevalence of thyroid pathology was identified in $18 \%(n=55)$ of patients, $11.8 \%(n=36)$ with subclinical hypothyroidism (Table S1). If the patients had subclinical hypothyroidism, they were treated; if it was overt hypothyroidism, they were sent to the endocrinologist (although they continued to see the gynecologist).

The thyroid profiles requested during this consultation were reviewed, specifically the TSH and T4L values. From this, the patient was classified as euthyroid, with subclinical or overt hypothyroidism, or hyperthyroid according to the guidelines of the American Thyroid Association [9]. TSH values during the first trimester are between 0.1 and $2.5 \mathrm{mU} / \mathrm{L}$ in normal patients. Values with TSH greater than $2.5 \mathrm{mU} / \mathrm{L}$ without T4L alteration are diagnosed with subclinical hypothyroidism while those with decreased T4L have overt hypothyroidism. In opposite cases, decreased TSH values would indicate thyrotoxicosis. We used an upper limit of $2.5 \mathrm{mU} / \mathrm{L}$ for the following reasons: (i) The study was conducted between January 2016 and December 2017, and the Guidelines of the American Thyroid Association 2017 was published after our study began; and (ii) in Mexico, reference tables per trimester of thyroid hormone values have not yet been generated. Additional variables to analyze in each patient record will be the presence of hypertensive disease in previous pregnancies, type II diabetes and chronic hypertension. This study combined the classification of subclinical and overt hypothyroidism; additionally, no patients presented thyrotoxicosis. 
Table 1. Women in first trimester of pregnancy dataset.

\begin{tabular}{|c|c|c|c|c|}
\hline Code & Variable & Conceptual Definition & Operational Definition & Data Type \\
\hline \multicolumn{5}{|c|}{ ANTHROPOMETRIC } \\
\hline Age & Age & $\begin{array}{l}\text { Years born Patient age at the first trimester prenatal control } \\
\text { consultation date }\end{array}$ & $\begin{array}{l}1=30>; 2=30-35 \\
3=35-40 ; 4=40<\end{array}$ & Continuous \\
\hline Weight & Weight & Weight measurement in kilograms $(\mathrm{kg})$ & $40.1-115.0$ & Continuous \\
\hline Size & Height & Height in meters (m) & $1.43-1.79$ & Continuous \\
\hline BMI & BMI & $\begin{array}{l}\text { It is defined as the weight of a person in kilograms divided by the } \\
\text { square of his height in meters }\left(\mathrm{k} / \mathrm{m}^{2}\right)\end{array}$ & $15.4-43.8$ & Continuous \\
\hline BMI-WHO & $\begin{array}{l}\text { Body mass index - WHO } \\
\text { classification }\end{array}$ & $\begin{array}{c}1=\text { Underweight if }<18.5 ; 2=\text { normal weight if } 18.5-24.9 \\
3=\text { overweight if } 25-29.9 ; 4=\text { obese class I if } 30-34.9 ; 5=\text { obese class II } \\
\text { if } 35-39.9 ; 6=\text { obese class III if }>=40\left(\mathrm{k} / \mathrm{m}^{2}\right)\end{array}$ & $1,2,3,4,5,6$ & Categorical \\
\hline \multicolumn{5}{|c|}{ GYNECOLOGICAL } \\
\hline $\mathrm{P}$ & Pregnancies & Number of pregnancies & $1-9$ & Discrete \\
\hline $\mathrm{D}$ & Vaginal Deliveries & Number of vaginal deliveries & $0,1,2,3$ & Discrete \\
\hline $\mathrm{C}$ & Caesarean Deliveries & Number of caesarean deliveries & $0,1,2,3,4$ & Discrete \\
\hline A & Abortions & Number of abortions & $0,1,2,3,4,5$ & Discrete \\
\hline E & Ectopic & Number of ectopic pregnancies & 0,1 & Discrete \\
\hline GW & GW & It is calculated using the LMP and the first ultrasound & $4-13$ & Discrete \\
\hline + DAYS & + DAYS & More days & $0-9$ & Discrete \\
\hline Total GW & Total GW & It is calculated using the LMP and the first ultrasound & $4.0-13.86$ & Continuous \\
\hline \multicolumn{5}{|c|}{ PATHOLOGICAL HISTORY } \\
\hline $\mathrm{CAH}$ & Chronic Arterial Hypertension & Presence of chronic arterial hypertension & $1=$ yes $; 0=$ no & Binary \\
\hline DM type II & DM type II & Presence of Diabetes Mellitus (DM) type II & $1=$ yes $; 0=$ no & Binary \\
\hline Previous HTN & Previous HTN & Presence hypertensive disease in previous pregnancies & $1=$ yes $; 0=$ no & Binary \\
\hline
\end{tabular}


Table 1. Cont.

\begin{tabular}{|c|c|c|c|c|}
\hline Code & Variable & Conceptual Definition & Operational Definition & Data Type \\
\hline \multicolumn{5}{|c|}{ RISK FACTORS } \\
\hline Age $>30$ & $>30$ & Patients over 30 years & $1=$ yes $; 0=$ no & Binary \\
\hline FHxTh & Family history of Thyroid Disease & Patients with a 1st family history of thyroid disease & $1=$ yes; $0=$ no & Binary \\
\hline ATD or Hypo T & $\begin{array}{l}\text { Autoimmune Thyroid Disease or } \\
\text { hypothyroidism }\end{array}$ & Patients with autoimmune thyroid disease or hypothyroidism & $1=$ yes; $0=$ no & Binary \\
\hline Goiter + & Goiter + & Presence of goiter & $1=$ yes $; 0=$ no & Binary \\
\hline $\mathrm{T}+$ Anti TPO & $\mathrm{T}+$ Anti TPO & $\begin{array}{l}\text { Presence of previous positive antibodies: anti-TPO, TRAb, and/or } \\
\text { anti-thyroglobulin }\end{array}$ & $\begin{array}{c}0=\text { not performed, } \\
1=\text { negative }, 2=\text { positive }\end{array}$ & Categorical \\
\hline Sx HypoT & SxHypoT & Patients with symptoms or signs suggestive of thyroid hypofunction. & $1=$ yes; $0=$ no & Binary \\
\hline Num Sx & NumSymptoms & Number of Symptoms or Signs Suggestive of Thyroid Hypofunction & $0,1,2,3,4,5$ & Discrete \\
\hline FI & Fatigue & Symptom/sign suggestive of Th Hypofunction & $1=$ yes; $0=$ no & Binary \\
\hline CNST & Constipation & Symptom/sign suggestive of Th Hypofunction & $1=$ yes $; 0=$ no & Binary \\
\hline Cold & Cold & Symptom/sign suggestive of Th Hypofunction & $1=$ yes; $0=$ no & Binary \\
\hline Myalgia & Myalgia & Symptom/sign suggestive of Th Hypofunction & $1=$ yes; $0=$ no & Binary \\
\hline + weight & + weight & Symptom/sign suggestive of Th Hypofunction & $1=$ yes $; 0=$ no & Binary \\
\hline Edema & Edema & Symptom/sign suggestive of Th Hypofunction & $1=$ yes $; 0=$ no & Binary \\
\hline Dry skin & Dry skin & Symptom/sign suggestive of Th Hypofunction & $1=$ yes $; 0=$ no & Binary \\
\hline$<$ Hair & Hair loss & Symptom/sign suggestive of Th Hypofunction & $1=$ yes $; 0=$ no & Binary \\
\hline T1D & Diabetes T1 & Presence of type I Diabetes & $1=$ yes $; 0=$ no & Binary \\
\hline $\mathrm{AD}$ & Autoimmune disease & Autoimmune disease & $1=$ yes $; 0=$ no & Binary \\
\hline Infertile & Infertile & $\begin{array}{l}\text { Patients with a history of inability to achieve a clinical pregnancy } \\
\text { after } 12 \text { months or more of unprotected sex according to WHO }\end{array}$ & $1=$ yes $; 0=$ no & Binary \\
\hline IVF/ICSI & IVF/ICSI & In vitro fertilization/intracytoplasmic sperm injection & $1=$ yes $; 0=$ no & Binary \\
\hline HхAB or РТВ & $\begin{array}{l}\text { History of Abortion or Preterm } \\
\text { Birth }\end{array}$ & History of abortion or preterm birth & $1=$ yes $; 0=$ no & Binary \\
\hline Prev. IRR & Prev. Irradiation neck or head & Prev. Irradiation neck or head & $1=$ yes $; 0=$ no & Binary \\
\hline Ant. ThSurg & Ant. Thyroid Surgery & Anterior thyroid surgery & $1=$ yes $; 0=$ no & Binary \\
\hline Current Tx with T4L & Current Tx with T4L & Patient undergoing replacement treatment with Levothyroxine & $1=$ yes; $0=$ no & Binary \\
\hline PresRF & Presence of some Risk Factor & Presence of any listed thyroid disease risk factor & $1=$ yes; $0=$ no & Binary \\
\hline
\end{tabular}


Table 1. Cont.

\begin{tabular}{|c|c|c|c|c|}
\hline Code & Variable & Conceptual Definition & Operational Definition & Data Type \\
\hline \multicolumn{5}{|c|}{ THYROID PATHOLOGY } \\
\hline TSH & TSH & TSH value reported in the first trimester Th profile & $\begin{array}{c}1=0.1<\mathrm{TSH}<2.5 \\
\mathrm{mU} / \mathrm{L} ; 0=\text { normal }\end{array}$ & Real \\
\hline T4 TOTAL & T4 TOTAL & T4 TOTAL value reported in the first trimester Th profile & $1.89-14.63$ & Continuous \\
\hline T4L & $\mathrm{T} 4 \mathrm{~L}$ & T4L value reported in the first trimester Th profile & $0.5-8.88$ & Continuous \\
\hline T3 TOTAL & T3 TOTAL & T3 TOTAL value reported in the first trimester Th profile & $0.98-173.04$ & Continuous \\
\hline DX Th & DX Thyroid Profile & $\begin{array}{l}\text { Diagnosis based on the TSH and T4L values of the American Thyroid } \\
\text { Association guidelines }\end{array}$ & $\begin{array}{l}1=\text { hypothyroidism; } \\
0=\text { healthy }\end{array}$ & Binary \\
\hline $\mathrm{TX}$ & $\mathrm{TX}$ & If treatment is indicated after obtaining thyroid profile results & $1=$ yes $; 0=$ no & Binary \\
\hline \multicolumn{5}{|c|}{ PREGNANCY COMPLICATIONS } \\
\hline HD with PG & $\begin{array}{l}\text { Hypertensive Disease Associated } \\
\text { with Pregnancy }\end{array}$ & $\begin{array}{l}\begin{array}{c}\text { Development of hypertensive disease from after the 20th week of } \\
\text { pregnancy }\end{array}\end{array}$ & $1=$ yes $; 0=$ no & Binary \\
\hline GD & Gestational Diabetes & $\begin{array}{l}\text { Impaired glucose levels detected during pregnancy according to the } \\
\text { American Diabetes Association } 2016\end{array}$ & $1=$ yes $; 0=$ no & Binary \\
\hline PROM & Premature Membrane Rupture & Rupture of amniotic membranes before the start of labor & $1=$ yes $; 0=$ no & Binary \\
\hline PTD & Preterm Delivery & Childbirth that occurs before 37 weeks of gestation & $1=$ yes $; 0=$ no & Binary \\
\hline \multicolumn{5}{|c|}{ PERINATAL RESULTS } \\
\hline SDS & SDS at Unpacking & $\begin{array}{l}\text { Weeks of Unemployment Gestation. It is calculated using the LMP } \\
\text { and the first ultrasound. }\end{array}$ & $29.1-41.2$ & Continuous \\
\hline Birth & Birth Route & Birth Route & $\begin{array}{l}1=\text { delivery } \\
2=\text { caesarean }\end{array}$ & Binary \\
\hline PW & Product weight & Measurement of the bodies in kilograms $(\mathrm{kg})$ & $1.190-4.385$ & Continuous \\
\hline Ps & Product size & Height in centimeters $(\mathrm{cm})$ & $30-54$ & Continuous \\
\hline Capurro & Capurro & Method to estimate the gestational age of a newborn & $38-41$ & Discrete \\
\hline
\end{tabular}


As secondary information, the perinatal results of each patient were collected in retrospect: Gestational age at delivery, birth route, weight, height and gestational age by the Capurro Method of the product. This study also included the presence or absence of maternal complications, such as the development of hypertensive diseases associated with pregnancy, gestational diabetes, membranes rupture and preterm delivery. We attempted to correlate these data to determine if there are differences between patients with hypothyroidism and the rest of the population studied.

After identifying a dossier that met the inclusion criteria, it was assigned an identification number within the database and it was necessary to fill in the different variables that conform to the pathological history, risk factors for the development of thyroid diseases, thyroid pathology, pregnancy complications and perinatal results. Of the patients, $70 \%$ were over 30 years old; all patients had complete clinical data and had tested TSH.

One of the main limitations during the implementation of the protocol was the inclusion rate of $71.6 \%$, in most cases as a result of incomplete records of relevant information, such as TSH values and perinatal results. The features that were mostly incomplete, and later removed from the study, are T4 Total, T4L, T3 Total, and Capurro. Chronical arterial hypertension and hair loss, variables associated with thyroid disease, had only one class and were also excluded from the study. A total of 49 features remained.

\subsection{Application on the Dataset}

Given a cohort of patients diagnosed with a certain disease, unsupervised machine learning models allow us to identify comorbidity clusters for that disease, which helps to define new possible risk fields. The proposed $k$-means model represents diseases in the feature space [82]. We theorize that the disease with similar characteristics would be clustered in the feature space.

To verify the effectiveness of $k$-means in identifying disease clusters, we qualitatively visualize the disease representation in the dimensional projection using centroid-based clustering. In doing so, we evaluate the potential of unsupervised machine learning in the discovery of clusters. We tested different combinations and chose the ones that generated the best visualization results for the feature space. To determine which $k$ instances in the training dataset are most similar to a new entry, a Euclidean distance measure is used [83]. In addition, data must be standardized to make features comparable with the same scale. Standardization consists of transforming the features so that they have mean zero and standard deviation one [84]. We use average and standard deviation for the standardization.

\subsection{Discovering Patient Subgroup}

One question that arises in the field of gynecology is whether patients can be stratified into subgroups in which they share similar medical characteristics and risks. To discover patient subgroups, we could leverage clustering analysis on the patient feature vectors by using the rows of patient-disease. In our experiments, we tested $k$-means clustering with seven different amounts of subgroups, ranging from 2 to 8 subgroups. To evaluate these subgroups, we carried out the Within Cluster Sum of Squares (WCSS) and silhouette with squared Euclidean distance to compare the patient subgroup results. In addition to SSE and Euclidian distance, we conducted statistical analysis on the demographics and number of patient subgroups diagnoses. Our goal was to evaluate whether the patient subgroups discovered by $k$-means model could differentiate patients into a defined cohort.

\subsubsection{Cluster Analysis}

We used Apache Spark 4.3 for cluster analysis. A $k$-means analysis was performed to find different clusters using the patient data. Feature selection, mapping features from high-dimension to low-dimension, was used to reduce the primary data. The cluster analysis carried out did not have any missing values. The main steps in the $k$-means algorithm are: (1) Randomly select initial cluster centers with the $k$-number to assign the centroids; (2) all the closest data points to the centroids will create a cluster; (3) and compute new centers for the clusters. We calculate the distance between the 
points and the center using the Euclidean distance. Steps 2 and 3 are repeated until the centroids stop moving. The decision of the number of $k$ is made through the elbow method [85] and silhouette and verified by random forests (RF) classifier [86].

\subsubsection{Statistical Analysis}

All statistical analyses were performed using the SPSS software package version 23.0 (SPSS Inc., Chicago, IL, USA). An analysis of each specific risk factor was performed as part of the screening for thyroid disease to determine if it was statistically significant in the sample. On the other hand, multiple comparisons were made between patients with subclinical hypothyroidism and patients without this pathology, assessing each variable within the study to determine if there is a statistically significant correlation of any of them with the pathology. Results were analyzed using descriptive statistics, means and ranges, Chi square for the crossing of nominal variables and $t$ de Student for differences in group means. A calculated difference of $p>0.05$ was statistically significant. Chi-squared was performed to check the significance of the binary and continuous variables, separately, between different clusters.

\subsection{Experiments}

To find the right cohort for women in the first trimester of pregnancy, we conducted four experiments using different sets of features with $k$-means: (1) We used the remaining 49 features and selected $k=2$; (2) we performed the analysis of all features without perinatal results (weeks of Unemployment Gestation, birth route, product weight, product size and Capurro) and pregnancy complications (hypertensive disease with pregnancy, gestational diabetes, premature rupture of membrane and preterm delivery) with $k=2$ and $k=3$; (3) we exclusively used the thyroid pathology to create new clusters using $k=2$; and (4) finally we used the risk factors to determine the new clusters with a $k=2$.

For each test a classification analysis is made with RF considering the next set of features: (1) All features; (2) risk factors; (3) thyroid features; (4) symptoms or signs suggesting thyroid hypofunction; (5) all features without thyroid data; (6) all features without perinatal, pregnancy and thyroid data; and (7) all features without perinatal data and pregnancy complications.

\section{Results}

\subsection{Determining Number of Clusters}

$k$-means requires that the number of clusters is determined in advance and supplied to the algorithm as a parameter. To measure the quality of the clusters, Figure 1 shows the elbow method and the average silhouette approach. The goal is to choose a small $k$-value that still has a low within-cluster sum of squares and a high silhouette. The results of the elbow method, the total within-cluster sum of squares, are ambiguous for (a) all features, and (b) all features without perinatal and pregnancy results. For (c) thyroid pathology the best cluster is $k=3$ and for (d) risk factors it is $k=4$. The highest value for the average silhouette is (a) $k=2$ at 0.31 , (b) $k=2$ at 0.34 , (c) $k=8$ at 0.93 and (d) $k=6$ at 0.58 . 

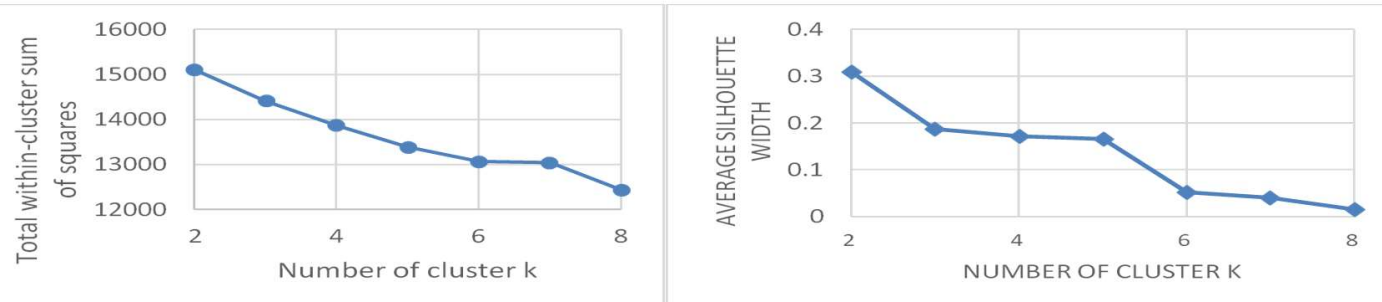

(a) All the features
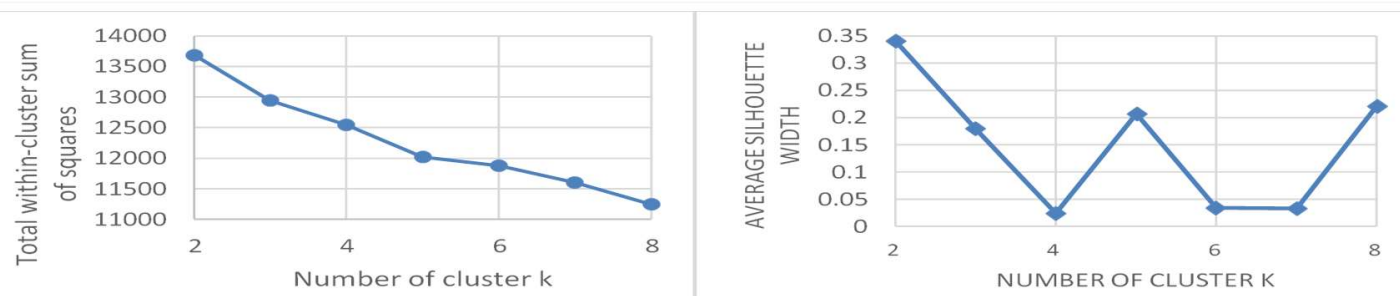

(b) All features without perinatal and pregnancy results
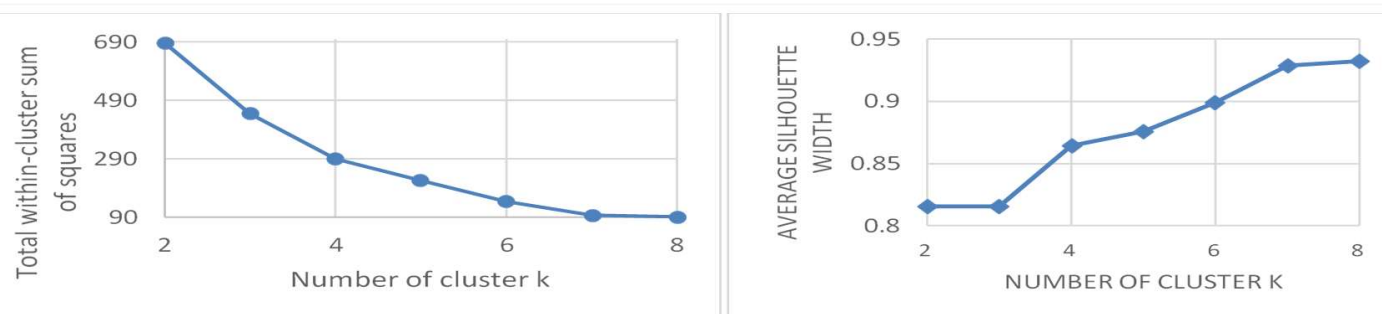

(c) Thyroid pathology

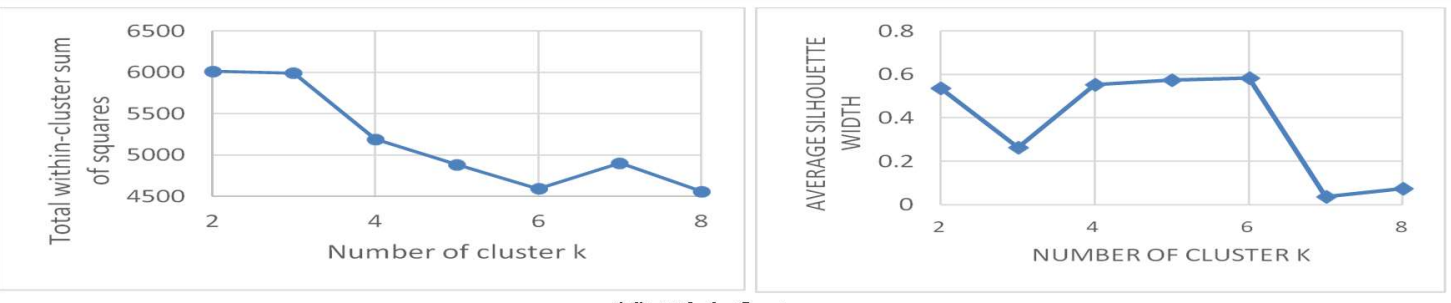

(d) Risk factors

Figure 1. Elbow method and the average silhouette.

Table 2 shows the clusters, from 2 to 8 , with the number of women in each one. In the case of (a) all features, after four clusters, the number of patients is small in some of the subgroups (i.e., Cluster 5 with 15 women in group 2). Based on the results provided by the silhouette, the best cluster number is $k=2$. Similar to (a) all features, after four clusters, the (b) features without perinatal and pregnancy results start to present clusters with small values (i.e., Cluster 5 with seven women in group 4) and the best cluster number should be $k=2$. Taking out clusters two and three, there is, for (c) thyroid pathology, a small number of women in the remaining clusters (i.e., Cluster 4 with 28 women in group 0 and 26 in group 2). The silhouette method has great results due to the small size of the subsets of the different clusters and is not reliable; based on this, we selected $k=2$ and $k=3$. After two clusters, for (d) risk factors, there is a small number of women (i.e., Cluster 3 with five women in group 1). According to these observations, we defined $k=2$ as the optimal number of clusters in the data. 
Table 2. Number of women in the first trimester pregnancy clusters.

\begin{tabular}{lcccccccc}
\hline & $\mathbf{0}$ & $\mathbf{1}$ & $\mathbf{2}$ & $\mathbf{3}$ & $\mathbf{4}$ & $\mathbf{5}$ & $\mathbf{6}$ & $\mathbf{7}$ \\
\hline Cluster 2 & 69 & 237 & & (a) All features & & & & \\
Cluster 3 & 71 & 167 & 68 & & & & & \\
Cluster 4 & 61 & 162 & 40 & 43 & & & & \\
Cluster 5 & 47 & 45 & 15 & 161 & 38 & & & \\
Cluster 6 & 36 & 81 & 59 & 89 & 39 & 2 & & \\
Cluster 7 & 51 & 78 & 47 & 3 & 14 & 33 & 80 & \\
Cluster 8 & 48 & 90 & 11 & 3 & 46 & 36 & 68 & 4 \\
\hline
\end{tabular}

(b) All features without perinatal results and pregnancy complications

\begin{tabular}{|c|c|c|c|c|c|c|c|c|}
\hline Cluster 2 & 65 & 241 & & & & & & \\
\hline Cluster 3 & 77 & 161 & 68 & & & & & \\
\hline Cluster 4 & 62 & 107 & 42 & 95 & & & & \\
\hline Cluster 5 & 45 & 51 & 43 & 160 & 7 & & & \\
\hline Cluster 6 & 63 & 122 & 62 & 3 & 23 & 33 & & \\
\hline Cluster 7 & 49 & 99 & 19 & 3 & 98 & 2 & 36 & \\
\hline Cluster 8 & 41 & 156 & 17 & 8 & 6 & 33 & 41 & 4 \\
\hline \multicolumn{9}{|c|}{ (c) Thyroid pathology } \\
\hline Cluster 2 & 56 & 250 & & & & & & \\
\hline Cluster 3 & 56 & 28 & 222 & & & & & \\
\hline Cluster 4 & 28 & 56 & 26 & 196 & & & & \\
\hline Cluster 5 & 27 & 196 & 9 & 48 & 26 & & & \\
\hline Cluster 6 & 27 & 196 & 9 & 32 & 26 & 16 & & \\
\hline Cluster 7 & 27 & 188 & 16 & 31 & 26 & 9 & 9 & \\
\hline Cluster 8 & 27 & 188 & 9 & 30 & 26 & 16 & 9 & 1 \\
\hline \multicolumn{9}{|c|}{ (d) Risk factors } \\
\hline Cluster 2 & 69 & 237 & & & & & & \\
\hline Cluster 3 & 49 & 5 & 252 & & & & & \\
\hline Cluster 4 & 234 & 65 & 5 & 2 & & & & \\
\hline Cluster 5 & 230 & 64 & 6 & 5 & 1 & & & \\
\hline Cluster 6 & 230 & 64 & 6 & 2 & 1 & 3 & & \\
\hline Cluster 7 & 74 & 179 & 6 & 2 & 1 & 41 & 3 & \\
\hline Cluster 8 & 74 & 176 & 1 & 2 & 6 & 40 & 3 & 4 \\
\hline
\end{tabular}

\subsection{Cluster Analysis}

Table S2 presented the mean and standard deviation of the features. The cluster analysis identified groups that were significantly different from each other. The anthropometric, gynecological, pathological history, risk factors, thyroid pathology and perinatal results were stratified according to phenogroup (Table 1). Key cohorts of each first-trimester pregnant women are as follows.

\subsubsection{All Features with $k=2$}

The cluster analysis identified two women clusters. Table 3 shows the complete baseline data for the 49 prespecified features according to the cluster.

Cluster $0(n=69)$ was the smallest cluster and mainly involved patients with risk factors. Women were likely to have at least one symptom or sign suggestive of thyroid hypofunction (average of 1.74); fatigue $(0.48 \pm 0.50)$ and constipation $(0.41 \pm 0.49)$ were the most prevalent features. In addition, all subjects had some risk factor involved and the presence of positive antibodies (0.06). These women had the lowest TSH level (0.06) and the highest number of diagnoses based on the thyroid profile $(0.32)$. Furthermore, they did not present autoimmune disease, type I diabetes, or previous irradiation to the neck or head. 
Table 3. Characteristics stratified by all features. Features are presented as mean \pm SD.

\begin{tabular}{|c|c|c|}
\hline Variable & Cluster $0(n=69)$ & Cluster $1(n=237)$ \\
\hline \multicolumn{3}{|c|}{ ANTHROPOMETRIC } \\
\hline Age & $1.90 \pm 0.73$ & $1.87 \pm 0.74$ \\
\hline Weight & $64.99 \pm 11.57$ & $64.40 \pm 11.56$ \\
\hline Height & $1.61 \pm 0.05$ & $1.62 \pm 0.06$ \\
\hline BMI & $24.99 \pm 4.27$ & $24.56 \pm 4.09$ \\
\hline Body mass index - WHO classification & $2.62 \pm 0.79$ & $2.48 \pm 0.79$ \\
\hline \multicolumn{3}{|c|}{ GYNECOLOGICAL } \\
\hline Pregnancies & $1.94 \pm 1.04$ & $2.19 \pm 1.32$ \\
\hline Vaginal Deliveries & $0.10 \pm 0.30$ & $0.22 \pm 0.41$ \\
\hline Caesarean Deliveries & $0.43 \pm 0.50$ & $0.42 \pm 0.49$ \\
\hline Abortions & $0.22 \pm 0.42$ & $0.22 \pm 0.41$ \\
\hline Ectopic & $0.01 \pm 0.12$ & $0.03 \pm 0.16$ \\
\hline GW & $8.57 \pm 2.65$ & $8.21 \pm 2.38$ \\
\hline + DAYS & $2.43 \pm 2.06$ & $2.09 \pm 2.10$ \\
\hline Total GW & $8.91 \pm 2.68$ & $8.51 \pm 2.37$ \\
\hline \multicolumn{3}{|c|}{ PATHOLOGICAL HISTORY } \\
\hline DM type II & $0.03 \pm 0.17$ & $0.01 \pm 0.11$ \\
\hline Previous HTN & $0.01 \pm 0.12$ & $0.03 \pm 0.16$ \\
\hline \multicolumn{3}{|c|}{ RISK FACTORS } \\
\hline$>30$ & $0.71 \pm 0.46$ & $0.70 \pm 0.46$ \\
\hline Family history of Thyroid Disease & $0.03 \pm 0.17$ & $0.03 \pm 0.16$ \\
\hline Autoimmune Thyroid Disease or Hypothyroidism & $0.03 \pm 0.17$ & $0.01 \pm 0.11$ \\
\hline Goiter + & $0.03 \pm 0.17$ & $0.00 \pm 0.00$ \\
\hline T+Anti TPO & $0.06 \pm 0.24$ & $0.00 \pm 0.00$ \\
\hline SxHipoT & $0.99 \pm 0.12$ & $0.00 \pm 0.00$ \\
\hline NumSymptoms & $1.74 \pm 1.31$ & $0.00 \pm 0.00$ \\
\hline Fatigue & $0.48 \pm 0.50$ & $0.00 \pm 0.00$ \\
\hline Constipation & $0.41 \pm 0.49$ & $0.00 \pm 0.00$ \\
\hline Cold & $0.07 \pm 0.26$ & $0.00 \pm 0.00$ \\
\hline Myalgia & $0.09 \pm 0.28$ & $0.00 \pm 0.00$ \\
\hline + weight & $0.12 \pm 0.32$ & $0.00 \pm 0.00$ \\
\hline Edema & $0.16 \pm 0.37$ & $0.00 \pm 0.00$ \\
\hline Dry skin & $0.04 \pm 0.21$ & $0.00 \pm 0.00$ \\
\hline Diabetes T1 & $0.00 \pm 0.00$ & $0.01 \pm 0.09$ \\
\hline Autoimmune disease & $0.00 \pm 0.00$ & $0.03 \pm 0.18$ \\
\hline Infertile & $0.09 \pm 0.28$ & $0.02 \pm 0.13$ \\
\hline IVF/ICSI & $0.06 \pm 0.24$ & $0.01 \pm 0.11$ \\
\hline History of Abortion or Preterm Birth & $0.17 \pm 0.38$ & $0.16 \pm 0.37$ \\
\hline Prev. Irradiation neck or head & $0.00 \pm 0.00$ & $0.01 \pm 0.09$ \\
\hline Ant. Thyroid Surgery & $0.01 \pm 0.12$ & $0.01 \pm 0.09$ \\
\hline Current Tx with T4L & $0.04 \pm 0.21$ & $0.01 \pm 0.11$ \\
\hline Presence of some Risk Factor & $1.00 \pm 0.00$ & $0.22 \pm 0.41$ \\
\hline
\end{tabular}


Table 3. Cont.

\begin{tabular}{|c|c|c|}
\hline Variable & Cluster $0(n=69)$ & Cluster $1(n=237)$ \\
\hline \multicolumn{3}{|c|}{ THYROID PATHOLOGY } \\
\hline TSH & $0.06 \pm 0.24$ & $0.14 \pm 0.34$ \\
\hline DX Thyroid Profile & $0.32 \pm 0.47$ & $0.14 \pm 0.35$ \\
\hline $\mathrm{TX}$ & $0.32 \pm 0.47$ & $0.12 \pm 0.33$ \\
\hline \multicolumn{3}{|c|}{ PREGNANCY COMPLICATIONS } \\
\hline Hypertensive Disease Associated with Pregnancy & $0.06 \pm 0.24$ & $0.02 \pm 0.13$ \\
\hline Gestational Diabetes & $0.10 \pm 0.30$ & $0.15 \pm 0.36$ \\
\hline Premature Membrane Rupture & $0.03 \pm 0.17$ & $0.08 \pm 0.27$ \\
\hline Preterm Delivery & $0.04 \pm 0.21$ & $0.06 \pm 0.24$ \\
\hline \multicolumn{3}{|c|}{ PERINATAL RESULTS } \\
\hline SDS at Unpacking & $38.54 \pm 1.31$ & $38.40 \pm 1.50$ \\
\hline Birth Route & $1.70 \pm 0.46$ & $1.73 \pm 0.44$ \\
\hline Product Weight & $3150.42 \pm 487.36$ & $3131.15 \pm 448.78$ \\
\hline Product size & $48.96 \pm 1.77$ & $48.77 \pm 2.39$ \\
\hline
\end{tabular}

Cluster 1 ( $n=237)$ was the largest, with $>2$ times more women than the other cluster. Significantly, all patients in this cluster did not have symptoms or signs suggesting thyroid hypofunction. The cluster had the highest rate of women with TSH reported (0.6) and the healthiest thyroid profile (0.14). Additionally, this cluster had the lowest levels of women with infertility (0.02) and IVF/ICSI treatments (0.01). No positive antibodies were present.

\subsubsection{All Features without Perinatal and Pregnancy Complication Results with $k=2$}

The cluster analysis identified two women clusters. Table 4 shows the complete baseline data for the 40 prespecified features according to the cluster.

Table 4. Characteristics stratified by all the features without perinatal and pregnancy complication results. Features are presented as mean $\pm \mathrm{SD}$.

\begin{tabular}{lcc}
\hline Variable & Cluster $\mathbf{0}(\boldsymbol{n}=\mathbf{6 5})$ & Cluster $\mathbf{1}(\boldsymbol{n} \mathbf{=} \mathbf{2 4 1})$ \\
\hline Age & ANTHROPOMETRIC & \\
\hline Weight & $1.80 \pm 0.73$ & $1.90 \pm 0.73$ \\
\hline Height & $68.40 \pm 13.50$ & $63.49 \pm 10.76$ \\
\hline BMI & $1.62 \pm 0.05$ & $1.62 \pm 0.06$ \\
\hline Body mass index - WHO classification & $25.96 \pm 4.81$ & $24.30 \pm 3.83$ \\
\hline & GYNECOLOGICAL & $2.45 \pm 0.73$ \\
\hline Pregnancies & $2.74 \pm 0.96$ & $2.12 \pm 1.20$ \\
\hline Vaginal Deliveries & $2.26 \pm 1.50$ & $0.21 \pm 0.41$ \\
\hline Caesarean Deliveries & $0.12 \pm 0.33$ & $0.39 \pm 0.49$ \\
\hline Abortions & $0.52 \pm 0.50$ & $0.20 \pm 0.40$ \\
\hline Ectopic & $0.29 \pm 0.46$ & $0.03 \pm 0.17$ \\
\hline GW & $0.00 \pm 0.00$ & $8.09 \pm 2.37$ \\
\hline+ DAYS & $9.03 \pm 2.60$ & $2.13 \pm 2.07$ \\
\hline Total GW & $2.32 \pm 2.16$ & $8.39 \pm 2.37$ \\
\hline
\end{tabular}


Table 4. Cont.

\begin{tabular}{|c|c|c|}
\hline Variable & Cluster $0(n=65)$ & Cluster $1(n=241)$ \\
\hline \multicolumn{3}{|c|}{ PATHOLOGICAL HISTORY } \\
\hline DM type II & $0.03 \pm 0.17$ & $0.01 \pm 0.11$ \\
\hline Previous HTN & $0.05 \pm 0.21$ & $0.02 \pm 0.13$ \\
\hline \multicolumn{3}{|c|}{ RISK FACTORS } \\
\hline$>30$ & $0.65 \pm 0.48$ & $0.71 \pm 0.45$ \\
\hline Family history of Thyroid Disease & $0.03 \pm 0.17$ & $0.02 \pm 0.16$ \\
\hline Autoimmune Thyroid Disease or Hypothyroidism & $0.05 \pm 0.21$ & $0.01 \pm 0.09$ \\
\hline Goiter + & $0.03 \pm 0.17$ & $0.00 \pm 0.00$ \\
\hline $\mathrm{T}+$ Anti TPO & $0.03 \pm 0.17$ & $0.01 \pm 0.09$ \\
\hline SxHipoT & $0.42 \pm 0.50$ & $0.17 \pm 0.38$ \\
\hline NumSymptoms & $0.85 \pm 1.31$ & $0.27 \pm 0.78$ \\
\hline Fatigue & $0.22 \pm 0.41$ & $0.08 \pm 0.27$ \\
\hline Constipation & $0.12 \pm 0.33$ & $0.08 \pm 0.28$ \\
\hline Cold & $0.05 \pm 0.21$ & $0.01 \pm 0.09$ \\
\hline Myalgia & $0.06 \pm 0.24$ & $0.01 \pm 0.09$ \\
\hline + weight & $0.09 \pm 0.29$ & $0.01 \pm 0.09$ \\
\hline Edema & $0.09 \pm 0.29$ & $0.02 \pm 0.14$ \\
\hline Dry skin & $0.05 \pm 0.21$ & $0.00 \pm 0.00$ \\
\hline Diabetes T1 & $0.02 \pm 0.12$ & $0.00 \pm 0.06$ \\
\hline Autoimmune disease & $0.03 \pm 0.17$ & $0.02 \pm 0.16$ \\
\hline Infertile & $0.09 \pm 0.29$ & $0.02 \pm 0.13$ \\
\hline IVF/ICSI & $0.05 \pm 0.21$ & $0.02 \pm 0.13$ \\
\hline History of Abortion or Preterm Birth & $0.18 \pm 0.39$ & $0.16 \pm 0.37$ \\
\hline Prev. Irradiation neck or head & $0.00 \pm 0.00$ & $0.01 \pm 0.09$ \\
\hline Ant. Thyroid Surgery & $0.03 \pm 0.17$ & $0.00 \pm 0.06$ \\
\hline Current Tx with T4L & $0.06 \pm 0.24$ & $0.01 \pm 0.09$ \\
\hline Presence of some Risk Factor & $0.58 \pm 0.50$ & $0.34 \pm 0.47$ \\
\hline \multicolumn{3}{|c|}{ THYROID PATHOLOGY } \\
\hline $\mathrm{TSH}$ & $0.12 \pm 0.33$ & $0.12 \pm 0.32$ \\
\hline DX Thyroid Profile & $0.38 \pm 0.49$ & $0.12 \pm 0.33$ \\
\hline $\mathrm{TX}$ & $0.37 \pm 0.49$ & $0.11 \pm 0.32$ \\
\hline \multicolumn{3}{|c|}{ PREGNANCY COMPLICATIONS } \\
\hline Hypertensive Disease Associated with Pregnancy & $0.05 \pm 0.21$ & $0.02 \pm 0.14$ \\
\hline Gestational Diabetes & $0.12 \pm 0.33$ & $0.14 \pm 0.35$ \\
\hline Premature Membrane Rupture & $0.05 \pm 0.21$ & $0.07 \pm 0.26$ \\
\hline Preterm Delivery & $0.08 \pm 0.27$ & $0.05 \pm 0.22$ \\
\hline \multicolumn{3}{|c|}{ PERINATAL RESULTS } \\
\hline SDS at Unpacking & $38.21 \pm 1.29$ & $38.49 \pm 1.49$ \\
\hline Birth Route & $1.72 \pm 0.45$ & $1.73 \pm 0.45$ \\
\hline Product Weight & $3144.89 \pm 420.96$ & $3132.96 \pm 467.06$ \\
\hline Product size & $48.57 \pm 2.16$ & $48.88 \pm 2.29$ \\
\hline
\end{tabular}


Cluster $0(n=65)$ was the smallest cluster and consisted mainly of women with risk factors. It is likely that all subjects in the cluster had almost one symptom or sign suggesting thyroid hypofunction (0.85). Fatigue $(0.22 \pm 0.41)$ was the predominant feature in the presence of signs or symptoms and more than half of the women had some risk factor. They had the highest number of diagnoses based on the thyroid profile (0.38). Furthermore, Cluster 0 women were overweight (BMI of 25.96), had a higher number of miscarriages (0.29) and did not present ectopic pregnancies.

Cluster $1(n=241)$ was the largest, with more than two-thirds of all the women in our study. It is important to note that most subjects did not present with symptoms or signs suggestive of thyroid hypofunction and only one-third of the women had any risk factor present. Women had fewer diagnoses based on the thyroid profile (0.12). Moreover, this cluster had the lowest levels of patients with infertility (0.02) and IVF/ICSI (0.02).

\subsubsection{All Features without Perinatal and Pregnancy Complications Results with $k=3$}

The cluster analysis identified three women clusters. Table 5 shows the complete baseline data for the 40 prespecified features according to the cluster.

Cluster $0(n=68)$ was the smallest and all the women had one or more risk factors. The women had almost two symptoms or signs suggestive of thyroid hypofunction, with an average of 1.75 and a standard deviation of 1.32. Fatigue (0.47) and constipation (0.41) were the predominant features in the presence of signs or symptoms, with dry skin being the least common factor (0.04). Among the clusters, this one had the largest number of women diagnosed with thyroid profile (0.32) and on treatment (0.32). This cluster was the only one with cases of positive antibodies $(0.06)$.

Cluster $1(n=161)$ was the largest, with less than half of all subjects in our study and had normal weight $(B M I=23.84)$. Importantly, all patients in this cluster presented no symptoms or signs suggesting thyroid hypofunction and $95 \%$ had no risk factors. Moreover, this cluster had the lowest number of women diagnosed with thyroid profile (0.09) and on TX treatment (0.08).

Cluster $2(n=77)$ were mainly overweight (BMI of 26.04) women between 30 and 35 years old. Gynecological values differed from those of Clusters 1 and 2. Women had more previous pregnancies $(3.19 \pm 1.66)$, vaginal deliveries $(0.30 \pm 0.46)$, cesarean deliveries $(0.58 \pm 0.50)$ and abortions $(0.51 \pm 0.50)$. While most women did not have low symptoms or signs suggestive of thyroid hypofunction, they did have higher risk factor values (0.57) compared to the other clusters, such as age over 30 years $(0.90 \pm 0.31)$, autoimmune disease $(0.09 \pm 0.29)$ and history of abortion or preterm birth $(0.44 \pm 0.50)$. They had the second highest rate of diagnosis thyroid profile $(0.25)$ and TX treatment $(0.21)$. In addition, the cluster presented a higher number of patients with previous hypertension (0.08) and values of pregnancy complications, such as gestational diabetes $(0.22)$, premature membrane rupture $(0.21)$ and preterm delivery $(0.16)$.

Table 5. Characteristics stratified by all features. Features are presented as mean \pm SD.

\begin{tabular}{lccc}
\hline Variable & Cluster $\mathbf{2}(\boldsymbol{n}=\mathbf{6 8})$ & Cluster $\mathbf{1}(\boldsymbol{n}=\mathbf{1 6 1})$ & Cluster 0 $(\boldsymbol{n}=\mathbf{7 7})$ \\
\hline Age & ANTHROPOMETRIC & & \\
\hline Weight & $1.87 \pm 0.69$ & $1.69 \pm 0.62$ & $2.29 \pm 0.82$ \\
\hline Height & $65.08 \pm 11.63$ & $62.34 \pm 9.26$ & $68.63 \pm 14.41$ \\
\hline BMI & $1.61 \pm 0.05$ & $1.62 \pm 0.06$ & $1.62 \pm 0.05$ \\
\hline Body mass index - WHO classification & $25.01 \pm 4.30$ & $23.84 \pm 3.39$ & $26.04 \pm 4.95$ \\
\hline & $2.63 \pm 0.79$ & $2.35 \pm 0.65$ & $2.73 \pm 1.00$ \\
\hline Pregnancies & GYNECOLOGICAL & & \\
\hline Vaginal Deliveries & $1.90 \pm 0.98$ & $1.73 \pm 0.77$ & $3.19 \pm 1.66$ \\
\hline Caesarean Deliveries & $0.09 \pm 0.29$ & $0.18 \pm 0.39$ & $0.30 \pm 0.46$ \\
\hline Abortions & $0.43 \pm 0.50$ & $0.34 \pm 0.48$ & $0.58 \pm 0.50$ \\
\hline
\end{tabular}


Table 5. Cont.

\begin{tabular}{|c|c|c|c|}
\hline Variable & Cluster $2(n=68)$ & Cluster $1(n=161)$ & Cluster $0(n=77)$ \\
\hline Ectopic & $0.01 \pm 0.12$ & $0.01 \pm 0.11$ & $0.05 \pm 0.22$ \\
\hline GW & $8.57 \pm 2.67$ & $7.98 \pm 2.41$ & $8.68 \pm 2.25$ \\
\hline + DAYS & $2.46 \pm 2.07$ & $2.14 \pm 2.20$ & $1.97 \pm 1.86$ \\
\hline Total GW & $2.92 \pm 2.70$ & $8.29 \pm 2.41$ & $8.96 \pm 2.23$ \\
\hline \multicolumn{4}{|c|}{ PATHOLOGICAL HISTORY } \\
\hline DM type II & $0.03 \pm 0.17$ & $0.00 \pm 0.00$ & $0.04 \pm 0.19$ \\
\hline Previous HTN & $0.01 \pm 0.12$ & $0.00 \pm 0.00$ & $0.08 \pm 0.27$ \\
\hline \multicolumn{4}{|c|}{ RISK FACTORS } \\
\hline$>30$ & $0.71 \pm 0.46$ & $0.60 \pm 0.49$ & $0.90 \pm 0.31$ \\
\hline Family history of Thyroid Disease & $0.03 \pm 0.17$ & $0.03 \pm 0.17$ & $0.01 \pm 0.11$ \\
\hline Autoimmune Thyroid Disease or Hypothyroidism & $0.03 \pm 0.17$ & $0.00 \pm 0.00$ & $0.04 \pm 0.19$ \\
\hline Goiter + & $0.03 \pm 0.17$ & $0.00 \pm 0.00$ & $0.00 \pm 0.00$ \\
\hline $\mathrm{T}+$ Anti TPO & $0.06 \pm 0.24$ & $0.00 \pm 0.00$ & $0.00 \pm 0.00$ \\
\hline SxHipoT & $0.99 \pm 0.12$ & $0.00 \pm 0.00$ & $0.01 \pm 0.11$ \\
\hline NumSymptoms & $1.75 \pm 1.32$ & $0.00 \pm 0.00$ & $0.01 \pm 0.11$ \\
\hline Fatigue & $0.47 \pm 0.50$ & $0.00 \pm 0.00$ & $0.01 \pm 0.11$ \\
\hline Constipation & $0.41 \pm 0.50$ & $0.00 \pm 0.00$ & $0.00 \pm 0.00$ \\
\hline Cold & $0.07 \pm 0.26$ & $0.00 \pm 0.00$ & $0.00 \pm 0.00$ \\
\hline Myalgia & $0.09 \pm 0.29$ & $0.00 \pm 0.00$ & $0.00 \pm 0.00$ \\
\hline + weight & $0.12 \pm 0.32$ & $0.00 \pm 0.00$ & $0.00 \pm 0.00$ \\
\hline Edema & $0.16 \pm 0.37$ & $0.00 \pm 0.00$ & $0.00 \pm 0.00$ \\
\hline Dry skin & $0.04 \pm 0.21$ & $0.00 \pm 0.00$ & $0.00 \pm 0.00$ \\
\hline Diabetes T1 & $0.00 \pm 0.00$ & $0.00 \pm 0.00$ & $0.03 \pm 0.16$ \\
\hline Autoimmune disease & $0.00 \pm 0.00$ & $0.01 \pm 0.08$ & $0.09 \pm 0.29$ \\
\hline Infertile & $0.09 \pm 0.29$ & $0.01 \pm 0.08$ & $0.04 \pm 0.19$ \\
\hline IVF/ICSI & $0.06 \pm 0.24$ & $0.00 \pm 0.00$ & $0.04 \pm 0.19$ \\
\hline History of Abortion or Preterm Birth & $0.18 \pm 0.38$ & $0.03 \pm 0.17$ & $0.44 \pm 0.50$ \\
\hline Prev. Irradiation neck or head & $0.00 \pm 0.00$ & $0.00 \pm 0.00$ & $0.03 \pm 0.16$ \\
\hline Ant. Thyroid Surgery & $0.01 \pm 0.12$ & $0.00 \pm 0.00$ & $0.03 \pm 0.16$ \\
\hline Current Tx with T4L & $0.04 \pm 0.21$ & $0.00 \pm 0.00$ & $0.04 \pm 0.19$ \\
\hline Presence of some Risk Factor & $1.00 \pm 0.00$ & $0.05 \pm 0.22$ & $0.57 \pm 0.50$ \\
\hline \multicolumn{4}{|c|}{ THYROID PATHOLOGY } \\
\hline TSH & $0.06 \pm 0.24$ & $0.12 \pm 0.33$ & $0.16 \pm 0.37$ \\
\hline DX Thyroid Profile & $0.32 \pm 0.47$ & $0.09 \pm 0.28$ & $0.25 \pm 0.43$ \\
\hline $\mathrm{TX}$ & $0.32 \pm 0.47$ & $0.08 \pm 0.27$ & $0.21 \pm 0.41$ \\
\hline \multicolumn{4}{|c|}{ PREGNANCY COMPLICATIONS } \\
\hline Hypertensive Disease Associated with Pregnancy & $0.06 \pm 0.24$ & $0.02 \pm 0.14$ & $0.01 \pm 0.11$ \\
\hline Gestational Diabetes & $0.10 \pm 0.31$ & $0.11 \pm 0.32$ & $0.22 \pm 0.42$ \\
\hline Premature Membrane Rupture & $0.01 \pm 0.12$ & $0.02 \pm 0.16$ & $0.21 \pm 0.41$ \\
\hline Preterm Delivery & $0.03 \pm 0.17$ & $0.02 \pm 0.14$ & $0.16 \pm 0.37$ \\
\hline \multicolumn{4}{|c|}{ PERINATAL RESULTS } \\
\hline SDS at Unpacking & $38.62 \pm 1.13$ & $38.74 \pm 0.98$ & $37.63 \pm 2.12$ \\
\hline Birth Route & $1.69 \pm 0.47$ & $1.71 \pm 0.45$ & $1.78 \pm 0.42$ \\
\hline Product Weight & $3172.19 \pm 455.93$ & $3166.80 \pm 406.39$ & $3037.63 \pm 542.46$ \\
\hline Product size & $49.05 \pm 1.63$ & $49.06 \pm 1.78$ & $48.07 \pm 3.29$ \\
\hline
\end{tabular}




\subsubsection{Thyroid Pathology $k=2$}

The cluster analysis identified two women clusters. Table 6 shows the complete baseline data for the three prespecified features according to the cluster.

Table 6. Characteristics stratified by thyroid pathology. Features are presented as mean \pm SD.

\begin{tabular}{|c|c|c|}
\hline Variable & Cluster $0(n=56)$ & Cluster $1(n=250)$ \\
\hline \multicolumn{3}{|c|}{ ANTHROPOMETRIC } \\
\hline Age & $1.84 \pm 0.73$ & $1.89 \pm 0.74$ \\
\hline Weight & $66.95 \pm 13.35$ & $63.99 \pm 11.06$ \\
\hline Height & $1.62 \pm 0.05$ & $1.62 \pm 0.06$ \\
\hline BMI & $25.43 \pm 4.81$ & $24.48 \pm 3.95$ \\
\hline Body mass index - WHO classification & $2.64 \pm 0.92$ & $2.48 \pm 0.76$ \\
\hline \multicolumn{3}{|c|}{ GYNECOLOGICAL } \\
\hline Pregnancies & $2.38 \pm 1.58$ & $2.08 \pm 1.18$ \\
\hline Vaginal Deliveries & $0.14 \pm 0.35$ & $0.20 \pm 0.40$ \\
\hline Caesarean Deliveries & $0.54 \pm 0.50$ & $0.40 \pm 0.49$ \\
\hline Abortions & $0.32 \pm 0.47$ & $0.19 \pm 0.39$ \\
\hline Ectopic & $0.00 \pm 0.00$ & $0.03 \pm 0.17$ \\
\hline GW & $9.02 \pm 2.54$ & $8.12 \pm 2.40$ \\
\hline + DAYS & $2.39 \pm 2.21$ & $2.12 \pm 2.06$ \\
\hline Total GW & $9.36 \pm 2.53$ & $8.43 \pm 2.40$ \\
\hline \multicolumn{3}{|c|}{ PATHOLOGICAL HISTORY } \\
\hline DM type II & $0.04 \pm 0.19$ & $0.01 \pm 0.11$ \\
\hline Previous HTN & $0.04 \pm 0.19$ & $0.02 \pm 0.14$ \\
\hline \multicolumn{3}{|c|}{ RISK FACTORS } \\
\hline$>30$ & $0.68 \pm 0.47$ & $0.70 \pm 0.46$ \\
\hline Family history of Thyroid Disease & $0.04 \pm 0.19$ & $0.02 \pm 0.15$ \\
\hline Autoimmune Thyroid Disease or Hypothyroidism & $0.05 \pm 0.23$ & $0.01 \pm 0.09$ \\
\hline Goiter + & $0.02 \pm 0.13$ & $0.00 \pm 0.06$ \\
\hline $\mathrm{T}+$ Anti TPO & $0.02 \pm 0.13$ & $0.01 \pm 0.11$ \\
\hline SxHipoT & $0.32 \pm 0.47$ & $0.20 \pm 0.40$ \\
\hline NumSymptoms & $0.75 \pm 1.39$ & $0.31 \pm 0.81$ \\
\hline Fatigue & $0.16 \pm 0.37$ & $0.10 \pm 0.30$ \\
\hline Constipation & $0.13 \pm 0.33$ & $0.08 \pm 0.28$ \\
\hline Cold & $0.05 \pm 0.23$ & $0.01 \pm 0.09$ \\
\hline Myalgia & $0.04 \pm 0.19$ & $0.02 \pm 0.13$ \\
\hline + weight & $0.05 \pm 0.23$ & $0.02 \pm 0.14$ \\
\hline Edema & $0.05 \pm 0.23$ & $0.03 \pm 0.18$ \\
\hline Dry skin & $0.05 \pm 0.23$ & $0.00 \pm 0.00$ \\
\hline Diabetes T1 & $0.02 \pm 0.13$ & $0.00 \pm 0.06$ \\
\hline Autoimmune disease & $0.04 \pm 0.19$ & $0.02 \pm 0.15$ \\
\hline Infertile & $0.07 \pm 0.26$ & $0.02 \pm 0.15$ \\
\hline IVF/ICSI & $0.04 \pm 0.19$ & $0.02 \pm 0.14$ \\
\hline History of Abortion or Preterm Birth & $0.20 \pm 0.40$ & $0.16 \pm 0.37$ \\
\hline Prev. Irradiation neck or head & $0.00 \pm 0.00$ & $0.01 \pm 0.09$ \\
\hline Ant. Thyroid Surgery & $0.02 \pm 0.13$ & $0.01 \pm 0.09$ \\
\hline Current Tx with T4L & $0.07 \pm 0.26$ & $0.01 \pm 0.09$ \\
\hline Presence of some Risk Factor & $0.52 \pm 0.50$ & $0.36 \pm 0.48$ \\
\hline
\end{tabular}


Table 6. Cont.

\begin{tabular}{|c|c|c|}
\hline Variable & Cluster $0(n=56)$ & Cluster $1(n=250)$ \\
\hline \multicolumn{3}{|c|}{ THYROID PATHOLOGY } \\
\hline TSH & $0.14 \pm 0.35$ & $0.11 \pm 0.32$ \\
\hline DX Thyroid Profile & $0.39 \pm 0.49$ & $0.13 \pm 0.34$ \\
\hline TX & $0.38 \pm 0.49$ & $0.12 \pm 0.33$ \\
\hline \multicolumn{3}{|c|}{ PREGNANCY COMPLICATIONS } \\
\hline Hypertensive Disease Associated with Pregnancy & $0.05 \pm 0.23$ & $0.02 \pm 0.14$ \\
\hline Gestational Diabetes & $0.09 \pm 0.29$ & $0.15 \pm 0.36$ \\
\hline Premature Membrane Rupture & $0.05 \pm 0.23$ & $0.07 \pm 0.26$ \\
\hline Preterm Delivery & $0.07 \pm 0.26$ & $0.05 \pm 0.22$ \\
\hline \multicolumn{3}{|c|}{ PERINATAL RESULTS } \\
\hline SDS at Unpacking & $38.21 \pm 1.33$ & $38.48 \pm 1.48$ \\
\hline Birth Route & $1.70 \pm 0.46$ & $1.73 \pm 0.44$ \\
\hline Product Weight & $3137.59 \pm 408.52$ & $3135.03 \pm 467.94$ \\
\hline Product size & $48.58 \pm 2.32$ & $48.86 \pm 2.25$ \\
\hline
\end{tabular}

Cluster 0 ( $n=56)$ had the lowest number of women and they mainly had higher risk factor values. These patients had the highest number of symptoms or signs suggestive a thyroid profile $(0.75 \pm 1.39)$. Furthermore, Cluster 0 women were more likely to be overweight (BMI of $25.43 \pm 4.81$ ), and half had presence of risk factors (0.52). Among the clusters, this one had the largest number of women diagnosed with a thyroid profile (0.39) and on TX treatment (0.38).

Cluster 1 ( $n=250$ ) was the largest, with more than three-quarters of all the subjects in our study. The women in this cluster had fewer symptoms or signs suggestive of thyroid hypofunction (0.31). Less women tended to be diagnosed with a thyroid profile $(0.13)$ and to take TX treatment $(0.12)$.

\subsubsection{Risk Factors $k=2$}

The cluster analysis identified two women clusters. Table 7 shows the complete baseline data for the 22 prespecified features according to the cluster.

Table 7. Characteristics stratified by risk factors. Features are presented as mean \pm SD.

\begin{tabular}{lcc}
\hline Variable & Cluster 0 $(\boldsymbol{n}=\mathbf{6 9})$ & Cluster $\mathbf{1}(\boldsymbol{n}=\mathbf{2 3 7})$ \\
\hline Age & ANTHROPOMETRIC & \\
\hline Weight & $1.90 \pm 0.73$ & $1.87 \pm 0.74$ \\
\hline Height & $64.99 \pm 11.57$ & $64.40 \pm 11.56$ \\
\hline BMI & $1.61 \pm 0.05$ & $1.62 \pm 0.06$ \\
\hline Body mass index - WHO classification & $24.99 \pm 4.27$ & $24.56 \pm 4.09$ \\
\hline & $2.62 \pm 0.79$ & $2.48 \pm 0.79$ \\
\hline Pregnancies & GYNECOLOGICAL & \\
\hline Vaginal Deliveries & $1.94 \pm 1.04$ & $2.19 \pm 1.32$ \\
\hline Caesarean Deliveries & $0.10 \pm 0.30$ & $0.22 \pm 0.41$ \\
\hline Abortions & $0.43 \pm 0.50$ & $0.42 \pm 0.49$ \\
\hline Ectopic & $0.22 \pm 0.42$ & $0.22 \pm 0.41$ \\
\hline GW & $0.01 \pm 0.12$ & $0.03 \pm 0.16$ \\
\hline+ DAYS & $8.57 \pm 2.65$ & $8.21 \pm 2.38$ \\
\hline Total GW & $2.43 \pm 2.06$ & $2.09 \pm 2.10$ \\
\hline
\end{tabular}


Table 7. Cont.

\begin{tabular}{|c|c|c|}
\hline Variable & Cluster $0(n=69)$ & Cluster $1(n=237)$ \\
\hline \multicolumn{3}{|c|}{ PATHOLOGICAL HISTORY } \\
\hline DM type II & $0.03 \pm 0.17$ & $0.01 \pm 0.11$ \\
\hline Previous HTN & $0.01 \pm 0.12$ & $0.03 \pm 0.16$ \\
\hline \multicolumn{3}{|c|}{ RISK FACTORS } \\
\hline$>30$ & $0.71 \pm 0.46$ & $0.70 \pm 0.46$ \\
\hline Family history of Thyroid Disease & $0.03 \pm 0.17$ & $0.03 \pm 0.16$ \\
\hline Autoimmune Thyroid Disease or Hypothyroidism & $0.03 \pm 0.17$ & $0.01 \pm 0.11$ \\
\hline Goiter + & $0.03 \pm 0.17$ & $0.00 \pm 0.00$ \\
\hline T+Anti TPO & $0.06 \pm 0.24$ & $0.00 \pm 0.00$ \\
\hline SxHipoT & $0.99 \pm 0.12$ & $0.00 \pm 0.00$ \\
\hline NumSymptoms & $1.74 \pm 1.31$ & $0.00 \pm 0.00$ \\
\hline Fatigue & $0.48 \pm 0.50$ & $0.00 \pm 0.00$ \\
\hline Constipation & $0.41 \pm 0.49$ & $0.00 \pm 0.00$ \\
\hline Cold & $0.07 \pm 0.26$ & $0.00 \pm 0.00$ \\
\hline Myalgia & $0.09 \pm 0.28$ & $0.00 \pm 0.00$ \\
\hline + weight & $0.12 \pm 0.32$ & $0.00 \pm 0.00$ \\
\hline Edema & $0.16 \pm 0.37$ & $0.00 \pm 0.00$ \\
\hline Dry skin & $0.04 \pm 0.21$ & $0.00 \pm 0.00$ \\
\hline Diabetes T1 & $0.00 \pm 0.00$ & $0.01 \pm 0.09$ \\
\hline Autoimmune disease & $0.00 \pm 0.00$ & $0.03 \pm 0.18$ \\
\hline Infertile & $0.09 \pm 0.28$ & $0.02 \pm 0.13$ \\
\hline IVF/ICSI & $0.06 \pm 0.24$ & $0.01 \pm 0.11$ \\
\hline History of Abortion or Preterm Birth & $0.17 \pm 0.38$ & $0.16 \pm 0.37$ \\
\hline Prev. Irradiation neck or head & $0.00 \pm 0.00$ & $0.01 \pm 0.09$ \\
\hline Ant. Thyroid Surgery & $0.01 \pm 0.12$ & $0.01 \pm 0.09$ \\
\hline Current Tx with T4L & $0.04 \pm 0.21$ & $0.01 \pm 0.11$ \\
\hline Presence of some Risk Factor & $1.00 \pm 0.00$ & $0.22 \pm 0.41$ \\
\hline \multicolumn{3}{|c|}{ THYROID PATHOLOGY } \\
\hline TSH & $0.06 \pm 0.24$ & $0.14 \pm 0.34$ \\
\hline DX Thyroid Profile & $0.32 \pm 0.47$ & $0.14 \pm 0.35$ \\
\hline $\mathrm{TX}$ & $0.32 \pm 0.47$ & $0.12 \pm 0.33$ \\
\hline \multicolumn{3}{|c|}{ PREGNANCY COMPLICATIONS } \\
\hline Hypertensive Disease Associated with Pregnancy & $0.06 \pm 0.24$ & $0.02 \pm 0.13$ \\
\hline Gestational Diabetes & $0.10 \pm 0.30$ & $0.15 \pm 0.36$ \\
\hline Premature Membrane Rupture & $0.03 \pm 0.17$ & $0.08 \pm 0.27$ \\
\hline Preterm Delivery & $0.04 \pm 0.21$ & $0.06 \pm 0.24$ \\
\hline \multicolumn{3}{|c|}{ PERINATAL RESULTS } \\
\hline SDS at Unpacking & $38.54 \pm 1.31$ & $38.40 \pm 1.50$ \\
\hline Birth Route & $1.70 \pm 0.46$ & $1.73 \pm 0.44$ \\
\hline Product Weight & $3150.42 \pm 487.36$ & $3131.15 \pm 448.78$ \\
\hline Product size & $48.96 \pm 1.77$ & $48.77 \pm 2.39$ \\
\hline
\end{tabular}


Cluster $0(n=69)$ had the lowest number of women and all presented risk factors. Most of the subjects were likely to have almost two symptoms or signs suggestive of thyroid hypofunction $(1.74 \pm 1.31)$. The highest risk factors were fatigue (0.48) and constipation (0.41). Moreover, all patients had risk factors, such as goiter (0.03) and positive antibodies (0.06). These patients made up the largest number of women with thyroid profile $(0.32 \pm 0.47)$ and who followed a TX treatment $(0.32 \pm 0.47)$.

Cluster $1(n=237)$ was the largest, with more than two-thirds of all the subjects in our study. Importantly, all women in this cluster did not present symptoms or signs suggestive of thyroid hypofunction and the presence of risk factor was low $(0.22 \pm 0.41)$. They had a small number of diagnoses based on the thyroid profile $(0.14 \pm 0.35)$ and TX treatment $(0.12 \pm 0.33)$.

\subsection{Clustering Prediction Using RF}

To further investigate predictability in the current patient population, random forest classifier was carried out after cluster analysis. We performed the validation of different clusters using seven sets of features: (i) All features; (ii) risk factors; (iii) thyroid features; (iv) symptoms or signs suggestive of thyroid hypofunction; (v) all features without thyroid data; (vi) all features without perinatal, pregnancy and thyroid data; and (vii) all features without perinatal data and pregnancy. The RF accuracy is shown in Table 8.

There was a tendency to higher accuracy when using all the features, and observing the results the risk value had a high weight in the subgroups of features. (e) Risk factors computed $100.00 \%$ in all the sets beside the one composed for the thyroid features. In the case of (a) all features, the accuracy was perfect using the set of risk factors and computed the worst result using the thyroid features. For the features without perinatal and pregnancy features, (b) and (c), the computation differed depending on the number of clusters, $k=2$ or $k=3$. The error in the accuracy of $(b)$ was due to a misclassification; Cluster 0 was computed as Cluster 1; (c) depends on the set of features, similar to the two clusters scenario, risk factors and all features; the misclassification was due to Cluster 0 being computed as Cluster 1. The rest of the sets misclassify in different clusters (i.e., Cluster 1 was predicted as Cluster 2 on four occasions; Cluster 2 was predicted as Cluster 0 on twelve occasions). (d) Thyroid pathology had a high accuracy when using all features, the thyroid features and all features without perinatal and pregnancy data.

Table 8. RF accuracy using seven sets of features.

\begin{tabular}{|c|c|c|c|c|c|}
\hline Features & (a) All Features & $\begin{array}{l}\text { (b) No Perinatal and } \\
\text { Pregnancy } k=2\end{array}$ & $\begin{array}{l}\text { (c) No Perinatal and } \\
\text { Pregnancy } k=3\end{array}$ & $\begin{array}{l}\text { (d) Thyroid } \\
\text { Pathology }\end{array}$ & $\begin{array}{l}\text { (e) Risk } \\
\text { Factors }\end{array}$ \\
\hline All features & $100.00 \%$ & $97.78 \%$ & $92.71 \%$ & $98.91 \%$ & $100.00 \%$ \\
\hline Risk factors & $100.00 \%$ & $80.61 \%$ & $87.75 \%$ & $72.04 \%$ & $100.00 \%$ \\
\hline Thyroid features & $81.00 \%$ & $97.53 \%$ & $55.68 \%$ & $97.67 \%$ & $76.53 \%$ \\
\hline $\begin{array}{l}\text { Symptoms or signs suggestive of } \\
\text { thyroid hypofunction }\end{array}$ & $98.94 \%$ & $77.22 \%$ & $80.58 \%$ & $76.92 \%$ & $100.00 \%$ \\
\hline All features without thyroid data & $98.60 \%$ & $77.43 \%$ & $93.13 \%$ & $75.90 \%$ & $100.00 \%$ \\
\hline $\begin{array}{l}\text { All features without perinatal, } \\
\text { pregnancy and thyroid data }\end{array}$ & $98.23 \%$ & $76.84 \%$ & $88.54 \%$ & $74.07 \%$ & $100.00 \%$ \\
\hline $\begin{array}{l}\text { All features without perinatal and } \\
\text { pregnancy data }\end{array}$ & $98.91 \%$ & $79.85 \%$ & $94.38 \%$ & $97.06 \%$ & $100.00 \%$ \\
\hline
\end{tabular}

\section{Discussion}

We applied a $k$-means clustering approach to a dataset from a recent large controlled trial of women in the first trimester of pregnancy to identify relevant phenotypes of thyroid pathology and risk factors. Women in each cluster varied considerably among several variables: Risk factors, age, weight and some pregnancy complications. We noted differential associations with risk factors and hypothyroidism (Figure 2). These findings underscore the significant heterogeneity that exists within the first trimester of pregnancy and the need for improved symptomatic phenotyping. 
To our knowledge, this is the first application of cluster analysis to identify distinct risk factors and demographic features in a cohort of first-trimester pregnant women with a thyroid profile, a disorder believed to involve multiple disease subtypes [87-91]. Several previous studies analyzed the clinically relevant features and maternal outcomes of hypothyroid and euthyroid pregnancy, leading to new insights about the classification of women with similar patterns [92-94]. While the impact of these studies contributes to the literature, none of them focus on first trimester pregnancy or risk factor of thyroid pathology.

The findings presented here are important for several reasons, especially considering that there are only a handful of statistically identical characteristics in all subgroups; this emphasizes the need to improve descriptions of hypothyroidism in pregnancy subtypes. We identified two clusters of women using all features, features without perinatal results and pregnancy, thyroid pathology and risk factors. These groups were the result of hypothyroidism that differed in frequency and rates, especially in symptoms or signs suggesting hypothyroidism (prevalence: Almost $100 \%$ vs. almost $0 \%$ ). Consequently, women in cluster 0 had a greater risk of fatigue, constipation, edema, positive antibodies and at least one symptom or sign suggesting hypothyroidism. Cluster 1 women seemed to be healthier, euthyroid and without risk factors and symptoms and signs that suggest hypothyroidism. According to the Organisation for Economic Co-operation and Development (OECD) [95], Mexico was the second most obese country of the 25 major economies, with $38.2 \%$ of Mexicans classified as obese, in 2015. Due to Mexico's prevalence of overweight people and obesity, weight cannot be generalized to other populations and some comorbidities may not change between different clusters. Fatigue and constipation are common in both hypothyroidism and pregnancy. The number and combination of symptoms and signs may indicate a relationship with the diagnosis and treatment of hypothyroidism. Previous studies found a higher rate of $20-40 \%$ positive antibodies in hypothyroid pregnancy $[94,96,97]$. Despite the low rate of positive antibodies, new Mexican studies should be conduct for comparison. Treatment of overt hypothyroidism is recommended during pregnancy [3]. In this study, the positive autoimmune tests were not applied to all the women.

The use of the features without perinatal results and pregnancy with $k=3$ gave additional information. Cluster 0 is represented by nearly two signs or symptoms related to hypothyroidism and has at least one risk factor, low pregnancy complications, a small TSH $(6 \%)$ and a higher number of women diagnosed with hypothyroidism (32\%). Cluster 1 was characterized by no symptoms or signs suggesting hypothyroidism and having low risk factors (5\%); TSH was the same as the average population (12\%) and the diagnosis of hypothyroidism was the lowest (9\%). Cluster 2 had more women $(16 \%)$ with TSH $>2.5 \mathrm{mU} / \mathrm{L}$ even with $25 \%$ previously diagnosed and in-treated. There are changes in thyroid function during pregnancy and usually previous doses are not enough to maintain optimal hormone levels. It is a changing hormonal system, so patients need to be monitored every few weeks and adjusted accordingly. In this study, a TSH blood test was performed during the first trimester for all pregnant patients that came for a prenatal care appointment (with and without treatment for hypothyroidism). Another reason is an increase in the TSH during pregnancy. The guidelines of the American Thyroid Association recommend monitoring TSH every four weeks until midgestation and at least once more around week 30 [3]. Subgroup analysis of maternal outcomes revealed a significant association of patients in this cluster with increased pregnancy complications, as the increase in patients with gestational diabetes $(22 \%)$, premature membrane rupture $(21 \%)$, preterm delivery $(16 \%)$ and overweight women. Previous studies have associated hypothyroidism with preterm delivery [98-100]. Study [101] associated subclinical hypothyroidism with premature delivery at $<20$ weeks and [102] at $<34$ weeks. A high TSH in early pregnancy was associated with a risk of gestational diabetes $[98,103]$ and premature membrane rupture [104,105]. A high TSH increased the risk of low birth weight [98,101]. In our study, this cluster birth weight was at least $100 \mathrm{~g}$ less than the others. Another study [106] concluded otherwise; for hypothyroidism they found higher weight at birth. 
(a) Characteristics by all features

\begin{tabular}{|c|c|}
\hline CLUSTER 0: 69 WOMEN & CLUSTER 1: 237 WOMEN \\
\hline $\begin{array}{l}\text { - At least } 1 \text { symptom or sign } \\
\text { suggesting hypothyroidism } \\
\text { - } 1 \text { or more risk factors } \\
\text { - Howest TSH } \\
\text { - } \text { diaghest hypothyroidism } \\
\text { - Presence of positive antibodies }\end{array}$ & $\begin{array}{l}\text { - No symptoms or signs suggesting } \\
\text { hypothyroidism } \\
\text { - Low presence of risk factors } \\
\text { - Lowest hypothyroidism diagnosed } \\
\text { - No positive antibodies }\end{array}$ \\
\hline
\end{tabular}

(b) Characteristics by all the features without perinatal and pregnancy complication $k=2$

\begin{tabular}{|c|c|}
\hline CLUSTER 0: 65 WOMEN & CLUSTER 1: 242 WOMEN \\
\hline $\begin{array}{l}\text { - Almost } 1 \text { symptom or sign } \\
\text { suggesting hypothyroidism } \\
\text { - Presence of risk factors } \\
\text { - Highest hypothyroidism } \\
\text { diagnosed } \\
\text { - Highest overweight }\end{array}$ & $\begin{array}{l}\text { - Low symptoms or signs suggesting } \\
\text { hypothyroidism } \\
\text { - Low presence of risk factors (1/3) } \\
\text { - Lower rate of hypothyroidism } \\
\text { diagnosed } \\
\text { - No positive antibodies }\end{array}$ \\
\hline
\end{tabular}

(c) Characteristics by all the features without perinatal and pregnancy complication $k=3$

\begin{tabular}{|c|c|c|}
\hline CLUSTER 0: 68 WOMEN & CLUSTER 1: 161 WOMEN & CLUSTER 2: 77 WOMEN \\
\hline $\begin{array}{l}\text { - Almost } 2 \text { symptom or sign } \\
\text { suggesting hypothyroidism } \\
\text { - } 1 \text { or more risk factors } \\
\text { - Lowest TSH } \\
\text { - Highest hypothyroidism } \\
\text { diagnosed } \\
\text { - Presence of positive antibodies }\end{array}$ & $\begin{array}{l}\text { - No symptoms or signs suggesting } \\
\text { hypothyroidism } \\
\text { - Low risk factors ( } 5 \%) \\
\text { - Lowest hypothyroidism diagnosed } \\
\text { - Tendency a normal weight }\end{array}$ & $\begin{array}{l}\text { - No symptom or sign suggesting } \\
\text { hypothyroidism } \\
\text { - Presence of risk factors }(57 \%) \\
\text { - Second highest hypothyroidism } \\
\text { diagnosed } \\
\text { - Highest overweight } \\
\text { - } 30 \text {-35 years old } \\
\text { - Highest gynecological rate }\end{array}$ \\
\hline
\end{tabular}

(d) Characteristics by thyroid pathology

\begin{tabular}{l|l}
\hline CLUSTER 0: 56 WOMEN & CLUSTER 1: 250 WOMEN \\
\hline $\begin{array}{l}\text { - High symptom or sign suggesting } \\
\text { hypothyroidism }\end{array}$ & $\begin{array}{l}\text { - Low symptoms or signs suggesting } \\
\text { - hypothyroidism }\end{array}$ \\
$\begin{array}{ll}\text { Tendency to overweight } & \text { - Low presence of risk factors }(1 / 3) \\
\text { diagnosed } & \text { - Lower rate of hypothyroidism } \\
& \text { diagnosed }\end{array}$ \\
\end{tabular}

(e) Characteristics by risk factors

\begin{tabular}{l|l}
\hline CLUSTER 0: 69 WOMEN & CLUSTER 1: 237 WOMEN \\
\hline $\begin{array}{l}\text { - Almost } 2 \text { symptom or sign } \\
\text { suggesting hypothyroidism }\end{array}$ & $\begin{array}{l}\text { - No symptoms or signs suggesting } \\
\text { hypothyroidism }\end{array}$ \\
$\begin{array}{l}\text { - } 1 \text { or more risk factors } \\
\text { - Lowest TSH }\end{array}$ & - Really low risk factors (22\%) \\
- Highest hypothyroidism & \\
diagnosed & \\
- Presence of positive antibodies & \\
and goiter &
\end{tabular}

Figure 2. Cluster associations of women in first trimester of pregnancy with risk factors of thyroid pathology.

No significant association was found between baseline characteristics and preconception TSH clusters with most anthropometric, gynecological and perinatal outcomes. While untreated hypothyroidism can negatively affect pregnancy, there are no data suggesting that women with properly treated hypothyroidism are at increased risk for any obstetric complication [3].

Several limitations of this analysis require consideration. First and foremost, the present study was a retrospective analysis with T4 TOTAL, T4L and T3 not measured according to general recommendations, despite adequate diagnosis and treatment. Furthermore, the results of this study cannot be generalized to all pregnant populations as was done in northern Mexico. Likewise, the positive autoimmune test was not applied to the entire pregnant population since anti-TPO antibodies are not regularly requested due to their high cost to the patient. However, this study can be regarded as a baseline of the Mexican population and these results serve to majorly emphasize the need for a novel multidimensional classification of first trimester pregnant women with higher risk of thyroid disease, in order to improve patient care. We therefore recommend a larger prospective to assess the associations between maternal hypothyroidism and outcome features.

\section{Conclusions}

This study was carried out to explore the features in women during the first trimester of pregnancy using cluster analysis. This study recruited 306 patients during the first trimester of pregnancy reporting TSH values. Three distinct groups were identified using cluster analysis: (1) overweight women more than 30 years old who lacked signs or symptoms suggestive of thyroid hypofunction and a relatively low number of patients with some risk factors and increased pregnancy complications; (2) women less than 30 years old without any signs or symptoms suggestive of thyroid hypofunction, and 
who had both a low risk factor presence and had been diagnosed with a low level of hypothyroidism; (3) women less than 30 years old with a higher diagnosis of hypothyroidism that presents some risk factors and signs or symptoms suggestive of thyroid hypofunction; this group lacked autoimmune diseases and previous neck or head irradiation.

Cluster analysis was shown to be a practical approach for investigating the heterogeneity of the hypothyroidism risk factors in women in the first trimester of pregnancy in clinical studies. Risk factors and pregnancy complications might be valuable for prediction of hypothyroidism in pregnancy when compared with healthy patients. However, large-scale prospective trials with more information of pathological history, risk factors, thyroid pathology and pregnancy complications are necessary for further analysis.

Supplementary Materials: The following are available online at http://www.mdpi.com/2077-0383/9/7/2247/s1, Table S1: Classification according to thyroid pathology, Table S2: Features presented with the mean \pm SD.

Author Contributions: Conceptualization, A.K.G.-E. and E.G.-P.; methodology, A.K.G.-E.; software, A.K.G.-E.; validation, C.S.-C., E.A. and A.H.E.H.; formal analysis, A.K.G.-E.; investigation, E.G.-P. and A.K.G.-E.; resources, C.S.-C. and A.C.R.; data curation, E.G.-P. and A.K.G.-E.; writing-original draft preparation, A.K.G.-E. and E.G.-P.; writing-review and editing, A.K.G.-E. and E.G.-P.; visualization, A.K.G.-E.; supervision, A.C.R., E.A. and A.H.E.H.; funding acquisition, A.C.R., A.K.G.-E. and E.G.-P. All authors have read and agreed to the published version of the manuscript.

Funding: This study was funded by the Consejo Nacional de Ciencia y Tecnología (CONACYT- Mexico; grant number: 568729) and by the Institute of Innovation and Technology Transfer of Nuevo Leon, Mexico.

Conflicts of Interest: The authors declare no conflict of interest. The funders had no role in the design of the study; in the collection, analyses, or interpretation of data; in the writing of the manuscript, or in the decision to publish the results.

\section{References}

1. Krassas, G.E.; Poppe, K.; Glinoer, D. Thyroid function and human reproductive health. Endocr. Rev. 2010, 31, 702-755. [CrossRef] [PubMed]

2. Negro, R.; Mestman, J.H. Thyroid disease in pregnancy. Best Pract. Res. Clin. Endocrinol. Metab. 2011, 25, 927-943. [CrossRef]

3. Alexander, E.K.; Pearce, E.N.; Brent, G.A.; Brown, R.S.; Chen, H.; Dosiou, C.; Grobman, W.A.; Laurberg, P.; Lazarus, J.H.; Mandel, S.J.; et al. 2017 guidelines of the american thyroid association for the diagnosis and management of thyroid disease during pregnancy and the postpartum. Thyroid 2017, 27, 315-389. [CrossRef] [PubMed]

4. Kahr, M.K.; Antony, K.M.; Delbeccaro, M.; Hu, M.; Aagaard, K.M.; Suter, M.A. Increasing maternal obesity is associated with alterations in both maternal and neonatal thyroid hormone levels. Clin. Endocrinol. 2016, 84, 551-557. [CrossRef] [PubMed]

5. García-Solís, P.; Carlos Solís-S, J.; Cristina García-Gaytá, A.; Amaranta Reyes-Mendoza, V.; Robles-Osorio, L.; Luis Hernández-Montiel, H.; Enrique Leo-Amador, G. Iodine nutrition status in pregnant women in mexico. Thyroid 2011, $m 21,1367-1371$. [CrossRef]

6. Glinoer, D. The importance of iodine nutrition during pregnancy. Public Health Nutr. 2007, 10, $1542-1546$. [CrossRef]

7. Pearce, E.N.; Lazarus, J.H.; Moreno-Reyes, R.; Zimmermann, M.B. Consequences of iodine deficiency and excess in pregnant women: An overview of current knowns and unknowns. Am. J. Clin. Nutr. 2016, 104, 918S-923S. [CrossRef]

8. Mehta, V.; Pusukuru, R.; Ghodke, B. Association of thyroid stimulating hormone and lipid profile in pregnancy. J. Med. Res. Innov. 2017, 1, AU1-AU6. [CrossRef]

9. Stagnaro-Green, A.; Abalovich, M.; Alexander, E.; Azizi, F.; Mestman, J.; Negro, R.; Nixon, A.; Pearce, E.N.; Soldin, O.P.; Sullivan, S.; et al. Guidelines of the american thyroid association for the diagnosis and management of thyroid disease during pregnancy and postpartum. Thyroid 2011, 21, 1081-1125. [CrossRef]

10. De Groot, L.; Abalovich, M.; Groot, D.; Abalovich, L.; Alexander, M.; Amino, E.K.; Barbour, N.; Cobin, L.; Sullivan, R.H. Management of thyroid dysfunction during pregnancy and postpartum: An endocrine society clinical practice guideline. J. Clin. Endocrinol. Metab. 2012, 97, 2543-2565. [CrossRef] [PubMed] 
11. De Escobar, G.M.; Obregón, M.J.; Escobar del Rey, F. Maternal thyroid hormones early in prenancy and fetal brain development. Best Pract. Res. Clin. Endocrinol. Metab. 2004, 18, 225-248. [CrossRef] [PubMed]

12. Patel, J.; Landers, K.; Li, H.; Mortimer, R.H.; Richard, K. Delivery of maternal thyroid hormones to the fetus. Trends Endocrinol. Metab. 2011, 22, 164-170. [CrossRef] [PubMed]

13. Ozdemir, H.; Akman, I.; Coskun, S.; Demirel, U.; Turan, S.; Bereket, A.; Bilgen, H.; Ozek, E. Clinical study maternal thyroid dysfunction and neonatal thyroid problems. Int. J. Endocrinol. 2013, 2013. [CrossRef] [PubMed]

14. Pearce, E.N. Monitoring and effects of iodine deficiency in pregnancy: Still an unsolved problem? Eur. J. Clin. Nutr. 2013, 67, 481-484. [CrossRef] [PubMed]

15. Moog, N.K.; Entringer, S.; Heim, C.; Wadhwa, P.D.; Kathmann, N.; Buss, C. Influence of maternal thyroid hormones during gestation on fetal brain development. Neuroscience 2017, 342, 68-100. [CrossRef]

16. Yoshihara, A.; Noh, J.Y.; Yamaguchi, T.; Ohye, H.; Sato, S.; Sekiya, K.; Kosuga, Y.; Suzuki, M.; Matsumoto, M.; Kunii, Y.; et al. Treatment of graves' disease with antithyroid drugs in the first trimester of pregnancy and the prevalence of congenital malformation. J. Clin. Endocrinol. Metab. 2012, 97, 2396-2403. [CrossRef]

17. Serrano, M.Á.S. Alteraciones de tiroides y embarazo: Resultados perinatales. Revista de Especialidades Médico-Quirúrgicas 2013, 18, 200-205. (In Spanish)

18. Abalovich, M.; Gutierrez, S.; Alcaraz, G.; Maccallini, G.; Garcia, A.; Levalle, O. Overt and subclinical hypothyroidism complicating pregnancy. Thyroid 2002, 12, 63-68. [CrossRef] [PubMed]

19. Casey, B.M.; Dashe, J.S.; Wells, C.E.; Mcintire, D.D.; Byrd, W.; Leveno, K.J.; Cunningham, F.G. Subclinical hypothyroidism and pregnancy outcomes. Obstet. Gynecol. 2005, 105, 239-245. [CrossRef]

20. Cleary-Goldman, J.; Malone, F.D.; Lambert-Messerlian, G.; Sullivan, L.; Canick, J.; Porter, T.F.; Luthy, D.; Gross, S.; Bianchi, D.W.; D'Alton, M.E. Maternal thyroid hypofunction and pregnancy outcome. Obstet. Gynecol. 2008, 112, 85-92. [CrossRef]

21. Männistö, T.; Vääräsmäki, M.; Pouta, A.; Hartikainen, A.-L.; Ruokonen, A.; Surcel, H.-M.; Bloigu, A.; Järvelin, M.-R.; Suvanto-Luukkonen, E. Perinatal outcome of children born to mothers with thyroid dysfunction or antibodies: A prospective population-based cohort study. J. Clin. Endocrinol. Metab. 2009, 94, 772-779. [CrossRef]

22. Männistö, T.; Vääräsmäki, M.; Pouta, A.; Hartikainen, A.L.; Ruokonen, A.; Surcel, H.M.; Bloigu, A.; Järvelin, M.R.; Suvanto, E. Thyroid dysfunction and autoantibodies during pregnancy as predictive factors of pregnancy complications and maternal morbidity in later life. J. Clin. Endocrinol. Metab. 2010, 95, 1084-1094. [CrossRef] [PubMed]

23. Negro, R.; Schwartz, A.; Gismondi, R.; Tinelli, A.; Mangieri, T.; Stagnaro-Green, A. Universal screening versus case finding for detection and treatment of thyroid hormonal dysfunction during pregnancy. J. Clin. Endocrinol. Metab. 2010, 95, 1699-1707. [CrossRef] [PubMed]

24. Benhadi, N.; Wiersinga, W.M.; Reitsma, J.B.; Vrijkotte, T.G.M.; Bonsel, G.J. Higher maternal TSH levels in pregnancy are associated with increased risk for miscarriage, fetal or neonatal death. Eur. J. Endocrinol. 2009, 160, 985-991. [CrossRef] [PubMed]

25. Carney, L.A.; Quinlan, J.D.; West, J.M. Thyroid disease in pregnancy. Am. Fam. Physician 2014, 89, $273-287$.

26. Chen, S.; Zhou, X.; Zhu, H.; Yang, H.; Gong, F.; Wang, L.; Zhang, M.; Jiang, Y.; Yan, C.; Li, J.; et al. Preconception TSH and pregnancy outcomes: A population-based cohort study in 184611 women. Clin. Endocrinol. 2017, 86, 816-824. [CrossRef]

27. Nazarpour, S.; Candidate, P.D.; Tehrani, R.; Azizi, F.; Tehrani, F.R. Thyroid dysfunction and pregnancy outcomes. Iran. J. Reprod. Med. 2015, 13, 387.

28. Smallridge, R.C.; Ladenson, P.W. Hypothyroidism in pregnancy: Consequences to neonatal health. J. Clin. Endocrinol. Metab. 2001, 86, 2349-2353. [CrossRef]

29. Tan, T.O.; Cheng, Y.W.; Caughey, A.B. Are women who are treated for hypothyroidism at risk for pregnancy complications? Am. J. Obstet. Gynecol. 2006, 194, 1-3. [CrossRef]

30. Taylor, P.N.; Minassian, C.; Rehman, A.; Iqbal, A.; Draman, M.S.; Hamilton, W.; Dunlop, D.; Robinson, A.; Vaidya, B.; Lazarus, J.H.; et al. TSH levels and risk of miscarriage in women on long-term levothyroxine: A community-based study. J. Clin. Endocrinol. Metab. 2014, 99, 3895-3902. [CrossRef]

31. Tudosa, R.; Vartej, P.; Horhoianu, I.; Ghica, C.; Mateescu, S.; Dumitrache, I. Maternal and fetal complications of the hypothyroidism-related pregnancy. Maedica 2010, 5, 116-123. [PubMed] 
32. Li, J.; Liu, A.; Liu, H.; Li, C.; Wang, W.; Han, C.; Wang, X.; Zhang, Y.; Teng, W.; Shan, Z. Maternal TSH levels at first trimester and subsequent spontaneous miscarriage: A nested case-control study. Endocr. Connect. 2019, 8, 1288-1293. [CrossRef]

33. Hernández, M.; López, C.; Soldevila, B.; Cecenarro, L.; Martínez-Barahona, M.; Palomera, E.; Rius, F.; Lecube, A.; Pelegay, M.J.; García, J.; et al. Impact of TSH during the first trimester of pregnancy on obstetric and foetal complications: Usefulness of $2.5 \mathrm{mIU} / \mathrm{L}$ cut-off value. Clin. Endocrinol. 2018, 88, 728-734. [CrossRef]

34. Khadilkar, S. Thyroid-Stimulating hormone values in pregnancy: Cutoff controversy continues? J. Obstet. Gynecol. India 2019, 69, 389-394. [CrossRef] [PubMed]

35. Li, C.; Shan, Z.; Mao, J.; Wang, W.; Xie, X.; Zhou, W.; Li, C.; Xu, B.; Bi, L.; Meng, T.; et al. Assessment of thyroid function during first-trimester pregnancy: What is the rational upper limit of serum tsh during the first trimester in chinese pregnant women? J. Clin. Endocrinol. Metab. 2014, 99, 73-79. [CrossRef]

36. Rosario, P.W.; Carvalho, M.; Calsolari, M.R. TSH reference values in the first trimester of gestation and correlation between maternal TSH and obstetric and neonatal outcomes: A prospective Brazilian study. Arch. Endocrinol. Metab. 2016, 60, 314-318. [CrossRef] [PubMed]

37. Castillo Lara, M.; Vilar Sánchez, Á.; Cañavate Solano, C.; Soto Pazos, E.; Iglesias Álvarez, M.; González Macías, C.; Ayala Ortega, C.; Moreno Corral, L.J.; Fernández Alba, J.J. Hypothyroidism screening during first trimester of pregnancy. BMC Pregnancy Childbirth 2017, 17, 438. [CrossRef] [PubMed]

38. Everitt, B.S. An R and S-PLUS®Companion to Multivariate Analysis; Springer: London, UK, 2005. [CrossRef]

39. Wardlaw, A.J.; Silverman, M.; Siva, R.; Pavord, I.D.; Green, R. Multi-dimensional phenotyping: Towards a new taxonomy for airway disease. Clin. Exp. Allergy 2005, 35, 1254-1262. [CrossRef]

40. Hinton, G.E.; Salakhutdinov, R.R. Reducing the dimensionality of data with neural networks. Science 2006, 313, 504-507. [CrossRef]

41. Ahmad, T.; Pencina, M.J.; Schulte, P.J.; O’Brien, E.; Whellan, D.J.; Piña, I.L.; Kitzman, D.W.; Lee, K.L.; O'Connor, C.M.; Felker, G.M. Clinical implications of chronic heart failure phenotypes defined by cluster analysis. J. Am. Coll. Cardiol. 2014, 64, 1765-1774. [CrossRef]

42. Andersson, C.; Lyass, A.; Xanthakis, V.; Larson, M.G.; Mitchell, G.F.; Cheng, S.; Vasan, R.S. Risk factor-based subphenotyping of heart failure in the community. PLOS ONE 2019, 14. [CrossRef] [PubMed]

43. Guo, Q.; Lu, X.; Gao, Y.; Zhang, J.; Yan, B.; Su, D.; Song, A.; Zhao, X.; Wang, G. Cluster analysis: A new approach for identification of underlying risk factors for coronary artery disease in essential hypertensive patients. Sci. Rep. 2017, 7. [CrossRef] [PubMed]

44. Kim, S.; Lim, M.-N.; Hong, Y.; Han, S.-S.; Lee, S.-J.; Kim, W.J. A cluster analysis of chronic obstructive pulmonary disease in dusty areas cohort identified three subgroups. BMC Pulm. Med. 2017, 17, 209. [CrossRef]

45. Vazquez Guillamet, R.; Ursu, O.; Iwamoto, G.; Moseley, P.L.; Oprea, T. Chronic obstructive pulmonary disease phenotypes using cluster analysis of electronic medical records. Health Inform. J. 2018, 24, 394-409. [CrossRef] [PubMed]

46. Weatherall, M.; Shirtcliffe, P.; Travers, J.; Beasley, R. Use of cluster analysis to define COPD phenotypes. Eur. Respir. J. 2010, 36, 472-474. [CrossRef]

47. Yoon, H.Y.; Park, S.Y.; Lee, C.H.; Byun, M.K.; Na, J.O.; Lee, J.S.; Lee, W.Y.; Yoo, K.H.; Jung, K.S.; Lee, J.H. Prediction of first acute exacerbation using COPD subtypes identified by cluster analysis. Int. J. COPD 2019, 14, 1389-1397. [CrossRef]

48. Deliu, M.; Sperrin, M.; Belgrave, D.; Custovic, A. Identification of asthma subtypes using clustering methodologies. Pulm. Ther. 2016, 2, 19-41. [CrossRef]

49. Ghebre, M.A.; Pang, P.H.; Diver, S.; Desai, D.; Bafadhel, M.; Haldar, K.; Kebadze, T.; Cohen, S.; Newbold, P.; Rapley, L.; et al. Biological exacerbation clusters demonstrate asthma and chronic obstructive pulmonary disease overlap with distinct mediator and microbiome profiles. J. Allergy Clin. Immunol. 2018, 141, 2027-2036.e12. [CrossRef]

50. Haldar, P.; Pavord, I.D.; Shaw, D.E.; Berry, M.A.; Thomas, M.; Brightling, C.E.; Wardlaw, A.J.; Green, R.H. Cluster analysis and clinical asthma phenotypes. Am. J. Respir. Crit. Care Med. 2008, 178, 218-224. [CrossRef]

51. Moore, W.C.; Meyers, D.A.; Wenzel, S.E.; Teague, W.G.; Li, H.; Li, X.; D’Agostino, R.; Castro, M.; Curran-Everett, D.; Fitzpatrick, A.M.; et al. Identification of asthma phenotypes using cluster analysis in the severe asthma research program. Am. J. Respir. Crit. Care Med. 2010, 181, 315-323. [CrossRef]

52. Tyler, R.; Coelho, C.; Tao, P.; Ji, H.; Noble, W.; Gehringer, A.; Gogel, S. Identifying tinnitus subgroups with cluster analysis. Am. J. Audiol. 2008, 17, S176-S184. [CrossRef] 
53. Van den Berge, M.J.C.; Free, R.H.; Arnold, R.; de Kleine, E.; Hofman, R.; van Dijk, J.M.C.; van Dijk, P. Cluster analysis to identify possible subgroups in tinnitus patients. Front. Neurol. 2017, 8, 115. [CrossRef] [PubMed]

54. Gandasi, N.R.; Yin, P.; Riz, M.; Chibalina, M.V.; Cortese, G.; Lund, P.E.; Matveev, V.; Rorsman, P.; Sherman, A.; Pedersen, M.G.; et al. $\mathrm{Ca}^{2+}$ channel clustering with insulin-containing granules is disturbed in type 2 diabetes. J. Clin. Investig. 2017, 127, 2353-2364. [CrossRef] [PubMed]

55. Schmidt, M.I.; Watson, R.L.; Duncan, B.B.; Metcalf, P.; Brancati, F.L.; Sharrett, A.R.; Davis, C.E.; Heiss, G. Clustering of dyslipidemia, hyperuricemia, diabetes, and hypertension and its association with fasting insulin and central and overall obesity in a general population. Atherosclerosis risk in communities study investigators. Metab. Clin. Exp. 1996, 45, 699-706. [CrossRef]

56. Ahlqvist, E.; Storm, P.; Käräjämäki, A.; Martinell, M.; Dorkhan, M.; Carlsson, A.; Vikman, P.; Prasad, R.B.; Aly, D.M.; Almgren, P.; et al. Novel subgroups of adult-onset diabetes and their association with outcomes: A data-driven cluster analysis of six variables. Lancet Diabetes Endocrinol. 2018, 6, 361-369. [CrossRef]

57. Dennis, J.M.; Shields, B.M.; Henley, W.E.; Jones, A.G.; Hattersley, A.T. Disease progression and treatment response in data-driven subgroups of type 2 diabetes compared with models based on simple clinical features: An analysis using clinical trial data. Lancet Diabetes Endocrinol. 2019, 7, 442-451. [CrossRef]

58. Zaharia, O.P.; Kuss, O.; Strassburger, K.; Burkart, V.; Szendroedi, J.; Roden, M. Diabetes clusters and risk of diabetes-associated diseases-Authors' reply. Lancet Diabetes Endocrinol. 2019, 7, 828-829. [CrossRef]

59. Dunn, K.M.; Campbell, P.; Jordan, K.P. Long-Term trajectories of back pain: Cohort study with 7-year follow-up. BMJ Open 2013, 3, e003838. [CrossRef]

60. Macedo, L.G.; Maher, C.G.; Latimer, J.; McAuley, J.H.; Hodges, P.W.; Rogers, W.T. Nature and determinants of the course of chronic low back pain over a 12-month period: A cluster analysis. Phys. Ther. 2014, 94, 210-221. [CrossRef]

61. Rabey, M.; Smith, A.; Beales, D.; Slater, H.; O'Sullivan, P. Differing psychologically derived clusters in people with chronic low back pain are associated with different multidimensional profiles. Clin. J. Pain 2016, 32, 1015-1027. [CrossRef]

62. Rabey, M.; Slater, H.; O'Sullivan, P.; Beales, D.; Smith, A. Somatosensory nociceptive characteristics differentiate subgroups in people with chronic low back pain: A cluster analysis. Pain 2015, 156, 1874-1884. [CrossRef] [PubMed]

63. Viniol, A.; Jegan, N.; Hirsch, O.; Leonhardt, C.; Brugger, M.; Strauch, K.; Barth, J.; Baum, E.; Becker, A. Chronic low back pain patient groups in primary care-A cross sectional cluster analysis. BMC Musculoskelet. Disord. 2013, 14, 294. [CrossRef] [PubMed]

64. Murphy, S.L.; Lyden, A.K.; Phillips, K.; Clauw, D.J.; Williams, D.A. Subgroups of older adults with osteoarthritis based upon differing comorbid symptom presentations and potential underlying pain mechanisms. Arthritis Res. Ther. 2011, 13, R135. [CrossRef] [PubMed]

65. Seok, H.; Choi, S.J.; Yoon, J.H.; Song, G.G.; Won, J.U.; Kim, J.H.; Roh, J.; Jung, J.H. The association between osteoarthritis and occupational clusters in the Korean population: A nationwide study. PLoS ONE 2017, 12. [CrossRef]

66. Van Spil, W.E.; Jansen, N.W.D.; Bijlsma, J.W.J.; Reijman, M.; DeGroot, J.; Welsing, P.M.J.; Lafeber, F.P.J.G. Clusters within a wide spectrum of biochemical markers for osteoarthritis: Data from CHECK, a large cohort of individuals with very early symptomatic osteoarthritis. Osteoarthr. Cartil. 2012, 20, 745-754. [CrossRef]

67. Lei, Q.; Zhou, X.; Zhou, Y.-H.; Mai, C.-Y.; Hou, M.-M.; Lv, L.-J.; Duan, D.-M.; Wen, J.-Y.; Lin, X.-H.; Wang, P.P.; et al. Prehypertension during normotensive pregnancy and postpartum clustering of cardiometabolic risk factors: A prospective cohort study. Hypertension 2016, 68, 455-463. [CrossRef]

68. McLaughlin, K.; Zhang, J.; Lye, S.J.; Parker, J.D.; Kingdom, J.C. Phenotypes of pregnant women who subsequently develop hypertension in pregnancy. J. Am. Heart Assoc. 2018, 7. [CrossRef]

69. Thadhani, R.; Mutter, W.P.; Wolf, M.; Levine, R.J.; Taylor, R.N.; Sukhatme, V.P.; Ecker, J.; Karumanchi, S.A. First trimester placental growth factor and soluble fms-like tyrosine kinase 1 and risk for preeclampsia. J. Clin. Endocrinol. Metab. 2004, 89, 770-775. [CrossRef]

70. Villa, P.M.; Marttinen, P.; Gillberg, J.; Inkeri Lokki, A.; Majander, K.; Ordén, M.R.; Taipale, P.; Pesonen, A.; Räikkönen, K.; Hämäläinen, E.; et al. Cluster analysis to estimate the risk of preeclampsia in the high-risk prediction and prevention of preeclampsia and intrauterine growth restriction (PREDO) study. PLoS ONE 2017, 12. [CrossRef] 
71. Gibbs, I.; Leavey, K.; Benton, S.J.; Grynspan, D.; Bainbridge, S.A.; Cox, B.J. Placental transcriptional and histologic subtypes of normotensive fetal growth restriction are comparable to preeclampsia. Gynecology 2019, 220, 110.e1-110.e21. [CrossRef]

72. Asri, H.; Mousannif, H.; Moatassime, H.A. Real-Time miscarriage prediction with SPARK. Procedia Comput. Sci. 2017, 113, 423-428. [CrossRef]

73. Sánchez-Páez, D.A.; Ortega, J.A. Reported patterns of pregnancy termination from demographic and health surveys. PLoS ONE 2019, 14. [CrossRef] [PubMed]

74. Freitas-Vilela, A.A.; Smith, A.D.A.C.; Kac, G.; Pearson, R.M.; Heron, J.; Emond, A.; Hibbeln, J.R.; Castro, M.B.T.; Emmett, P.M. Dietary patterns by cluster analysis in pregnant women: Relationship with nutrient intakes and dietary patterns in 7-year-old offspring. Matern. Child Nutr. 2017, 13, e12353. [CrossRef] [PubMed]

75. Park, J.J.H.; Harari, O.; Siden, E.; Zoratti, M.; Dron, L.; Zannat, N.-E.; Lester, R.T.; Thorlund, K.; Mills, E.J. Interventions to improve birth outcomes of pregnant women living in low-and middle-income countries: A systematic review and network meta-analysis [version 1; peer review: Awaiting peer review]. Gates Open Res. 2019, 3, 1657. [CrossRef]

76. Segni, M.; Wood, J.; Pucarelli, I.; Toscano, V.; Toscano, R.; Pasquino, A.M. Clustering of autoimmune thyroid diseases in children and adolescents: A study of 66 families. J. Pediatric Endocrinol. Metab. 2001, 14, 1271-1275.

77. Amin, R.; Burns, J.J. Clusters of adolescent and young adult thyroid cancer in Florida counties. BioMed Res. Int. 2014, 2014, 832573. [CrossRef]

78. Fei, X.; Chen, W.; Zhang, S.; Liu, Q.; Zhang, Z.; Pei, Q. The spatio-temporal distribution and risk factors of thyroid cancer during rapid urbanization-A case study in China. Sci. Total Environ. 2018, 630, 1436-1445. [CrossRef]

79. Nakaya, T.; Takahashi, K.; Takahashi, H.; Yasumura, S.; Ohira, T.; Ohto, H.; Ohtsuru, A.; Midorikawa, S.; Suzuki, S.; Shimura, H.; et al. Spatial analysis of the geographical distribution of thyroid cancer cases from the first-round thyroid ultrasound examination in Fukushima Prefecture. Sci. Rep. 2018, 8, 1-11. [CrossRef]

80. Azar, A.T.; El-Said, S.A.; Hassanien, A.E. Fuzzy and hard clustering analysis for thyroid disease. Comput. Methods Programs Biomed. 2013, 111, 1-16. [CrossRef]

81. Azar, A.T.; Hassanien, A.E.; Kim, T.H. Expert system based on neural-fuzzy rules for thyroid diseases diagnosis. Commun. Comput. Inf. Sci. 2012, 353, 94-105. [CrossRef]

82. Bahmani, B.; Moseley, B.; Vattani, A.; Kumar, R.; Vassilvitskii, S. Scalable K-Means++. Proc. VLDB Endow. 2012, 5, 622-633. [CrossRef]

83. Singh, A.; Yadav, A.; Rana, A. K-Means with three different distance metrics. Int. J. Comput. Appl. 2013, 67, 13-17. [CrossRef]

84. Kaufman, L.; Rousseeuw, P.J. Finding Groups in Data: An Introduction to Cluster Analysis; Wiley-Interscience: Hoboken, NJ, USA, 1990.

85. Kodinariya, T.M.; Makwana, P.R. Review on determining number of cluster in k-means clustering. Int. J. Adv. Res. Comput. Sci. Manag. Stud. 2013, 1,90-95.

86. Breiman, L. Random forests. Mach. Learn. 2001, 45, 5-32. [CrossRef]

87. Carlé, A.; Laurberg, P.; Pedersen, I.B.; Knudsen, N.; Perrild, H.; Ovesen, L.; Rasmussen, L.B.; Jorgensen, T. Epidemiology of subtypes of hypothyroidism in Denmark. Eur. J. Endocrinol. 2006, 154, 21-28. [CrossRef]

88. Fountoulakis, K.N.; Iacovides, A.; Grammaticos, P.; St. Kaprinis, G.; Bech, P. Thyroid function in clinical subtypes of major depression: An exploratory study. BMC Psychiatry 2004, 4, 6. [CrossRef]

89. Kitahara, C.M.; Körmendiné Farkas, D.; Jørgensen, J.O.L.; Cronin-Fenton, D.; Sørensen, H.T. Benign Thyroid diseases and risk of thyroid cancer: A nationwide cohort study. J. Clin. Endocrinol. Metab. 2018, 103, 2216-2224. [CrossRef] [PubMed]

90. Luiz, H.V.; Gonçalves, D.; da Silva, T.N.; Nascimento, I.; Ribeiro, A.; Mafra, M.; Manita, I.; Portugal, J. Tireoidite de Hashimoto associada a IgG4-Uma nova variante de uma doença bem conhecida. Arq. Bras. Endocrinol. Metabol. 2014, 58, 862-868. [CrossRef]

91. Slatosky, J.; Shipton, B.; Wahba, H. Thyroiditis: Differential diagnosis and management. Am. Fam. Physician 2000, 61, 1047-1052. [PubMed]

92. Frank, A.S.; Lupattelli, A.; Matteson, D.S.; Nordeng, H. Maternal use of thyroid hormone replacement therapy before, during, and after pregnancy: Agreement between self-report and prescription records and group-based trajectory modeling of prescription patterns. Clin. Epidemiol. 2018, 10, 1801-1816. [CrossRef] 
93. Horacek, J.; Spitalnikova, S.; Dlabalova, B.; Malirova, E.; Vizda, J.; Svilias, I.; Cepkova, J.; Mc Grath, C.; Maly, J. Universal screening detects two-times more thyroid disorders in early pregnancy than targeted high-risk case finding. Eur. J. Endocrinol. 2010, 163, 645-650. [CrossRef] [PubMed]

94. Kiran, Z.; Sheikh, A.; Malik, S.; Meraj, A.; Masood, M.; Ismail, S.; Rashid, M.O.; Shaikh, Q.; Majeed, N.; Sheikh, L.; et al. Maternal characteristics and outcomes affected by hypothyroidism during pregnancy (maternal hypothyroidism on pregnancy outcomes, MHPO-1). BMC Pregnancy Childbirth 2019, $19,476$. [CrossRef] [PubMed]

95. OECD. Obesity Update. Available online: https://www.oecd.org/health/obesity-update.htm (accessed on 19 March 2020).

96. Dhanwal, D.; Bajaj, S.; Rajput, R.; Subramaniam, K.A.V.; Chowdhury, S.; Bhandari, R.; Dharmalingam, M.; Sahay, R.; Ganie, A.; Kotwal, N.; et al. Prevalence of hypothyroidism in pregnancy: An epidemiological study from 11 cities in 9 states of India. Indian J. Endocrinol. Metab. 2016, 20, 387. [CrossRef] [PubMed]

97. Reh, A.; Grifo, J.; Danoff, A. What is a normal thyroid-stimulating hormone (TSH) level? Effects of stricter TSH thresholds on pregnancy outcomes after in vitro fertilization. Fertil. Steril. 2010, 94, 2920-2922. [CrossRef]

98. Karakosta, P.; Alegakis, D.; Georgiou, V.; Roumeliotaki, T.; Fthenou, E.; Vassilaki, M.; Boumpas, D.; Castanas, E.; Kogevinas, M.; Chatzi, L. Thyroid dysfunction and autoantibodies in early pregnancy are associated with increased risk of gestational diabetes and adverse birth outcomes. J. Clin. Endocrinol. Metab. 2012, 97, 4464-4472. [CrossRef] [PubMed]

99. Schneuer, F.J.; Nassar, N.; Tasevski, V.; Morris, J.M.; Roberts, C.L. Association and predictive accuracy of high TSH serum levels in first trimester and adverse pregnancy outcomes. J. Clin. Endocrinol. Metab. 2012, 97, 3115-3122. [CrossRef]

100. Stagnaro-Ǵreen, A.; Chen, X.; Bogden, J.D.; Davies, T.F.; Scholl, T.O. The thyroid and pregnancy: A novel risk factor for very preterm delivery. Thyroid 2005, 15, 351-357. [CrossRef]

101. Su, P.Y.; Huang, K.; Hao, J.H.; Xu, Y.Q.; Yan, S.Q.; Li, T.; Xu, Y.H.; Tao, F.B. Maternal thyroid function in the first twenty weeks of pregnancy and subsequent fetal and infant development: A prospective populationbased cohort study in China. J. Clin. Endocrinol. Metab. 2011, 96, 3234-3241. [CrossRef] [PubMed]

102. Casey, B.M.; Dashe, J.S.; Spong, C.Y.; McIntire, D.D.; Leveno, K.J.; Cunningham, G.F. Perinatal significance of isolated maternal hypothyroxinemia identified in the first half of pregnancy. Obstet. Gynecol. 2007, 109, 1129-1135. [CrossRef]

103. Gong, L.L.; Liu, H.; Liu, L.H. Relationship between hypothyroidism and the incidence of gestational diabetes: A meta-analysis. Taiwan. J. Obstet. Gynecol. 2016, 55, 171-175. [CrossRef]

104. Chen, L.-M.; Du, W.-J.; Dai, J.; Zhang, Q.; Si, G.-X.; Yang, H.; Ye, E.-L.; Chen, Q.-S.; Yu, L.-C.; Zhang, C.; et al. Effects of subclinical hypothyroidism on maternal and perinatal outcomes during pregnancy: A single-center cohort study of a chinese population. PLoS ONE 2014, 9, e109364. [CrossRef] [PubMed]

105. Männistö, T.; Mendola, P.; Grewal, J.; Xie, Y.; Chen, Z.; Laughon, S.K. Thyroid diseases and adverse pregnancy outcomes in a contemporary US cohort. J. Clin. Endocrinol. Metab. 2013, 98, 2725-2733. [CrossRef] [PubMed]

106. Andersen, S.L.; Olsen, J.; Wu, C.S.; Laurberg, P. Low birth weight in children born to mothers with hyperthyroidism and high birth weight in hypothyroidism, whereas preterm birth is common in both conditions: A danish national hospital register study. Eur. Thyroid J. 2013, 2, 135. [CrossRef] [PubMed]

(C) 2020 by the authors. Licensee MDPI, Basel, Switzerland. This article is an open access article distributed under the terms and conditions of the Creative Commons Attribution (CC BY) license (http://creativecommons.org/licenses/by/4.0/). 